\title{
Nadane stopnie i tytuły naukowe - czy coś się zmieniło?
}

STRESZCZENIE. Artykuł poświęcony jest trendom w obszarze nadawanych w kraju stopni naukowych doktora i doktora habilitowanego, stopni w zakresie sztuki oraz tytułu naukowego profesora i tytułu profesora w zakresie sztuki. Podczas prezentacji wyników uwzględniono podział osób uzyskujących stopnie i tytuły według płci. Pokazano, jak zmienia się liczba osób, którym nadano stopnie i tytuły w kolejnych latach. Omówiono strukturę nadanych stopni/tytułów w poszczególnych obszarach nauki i sztuki. Określono również, jak zmienia się liczba nadanych stopni i tytułów w poszczególnych latach w zależności od wieku osób uzyskujących stopień lub tytuł. Analizy oparto na danych jednostkowych znajdujących się w Bazie Wiedzy o Nauce Polskiej i obejmujących ostatnie 16 lat (2000-2015).

SŁOWA KLUCZOWE: stopnie naukowe, tytuły naukowe, płeć, obszar badań naukowych

\section{Wstęp}

Stopnie i tytuły naukowe są stałym elementem rozwoju kariery naukowej. Ważny jest nie tylko fakt posiadania określonego stopnia lub tytułu, ale również wiek, w którym się go uzyskało. Posiadanie wysokiego stopnia czy tytułu naukowego nie jest jednak warunkiem koniecznym tworzenia najważniejszych osiągnięć naukowych lub uzyskiwania wybitnych wyników w twórczości artystycznej. Problem porównania awansu naukowego kobiet i mężczyzn systematycznie poruszany jest w publikacjach krajowych (np. Kwiek 2015) i międzynarodowych (np. She Figures 2015), ale nie został jeszcze do końca przeanalizowany. Uzyskiwanie stopnia/ tytułu przez osobę danej płci w określonym wieku niewątpliwie zależy od obszaru nauki lub sztuki, w którym został nadany stopień czy tytuł. Ale w jakim stopniu? Spostrzeżenia zamieszczone w artykule Kto zdobywa stopnie i tytuty naukowe - 
trochę statystyki (Rodzik 2009) z jednej strony wskazywały na starzenie się kadry naukowej zdobywającej tytuły naukowe, z drugiej - na wzrost pozycji kobiet w nauce. Czy coś zmieniło się w ciągu ostatnich 7 lat? Niniejszy tekst jest próbą odpowiedzi na to pytanie.

Artykuł składa się z trzech części. W pierwszej przedstawiono zastosowany zakres klasyfikacji obszarów nauki i sztuki oraz omówiono wiarygodność wykorzystanych do obliczeń danych. W drugiej ukazano wyniki obliczeń oraz obserwacje uzyskane na ich podstawie dla nadanych w poszczególnych latach stopni (doktora nauk i doktora sztuki oraz doktora habilitowanego nauk i doktora habilitowanego sztuki) i tytułów (profesor nauk i profesor sztuki). W trzeciej podsumowano obserwacje przedstawione w części drugiej.

Wszystkie wyniki zamieszczone w artykule, o ile nie zaznaczono inaczej, zostały wyliczone na podstawie zawartości Bazy Wiedzy o Nauce Polskiej (BWNP) ${ }^{1}$, prowadzonej przez Ośrodek Przetwarzania Informacji - Państwowy Instytut Badawczy.

\section{Zastosowana klasyfikacja}

Do 2011 r. w odniesieniu do nadawanych stopni i tytułów naukowych nie istniało pojęcie obszarów nauki i sztuki. W dniu 8 sierpnia 2011 r. ukazało się rozporządzenie Ministra Nauki i Szkolnictwa Wyższego definiujące pojęcie i zakres poszczególnych obszarów nauki i sztuki (dalej ta klasyfikacja będzie nazywana „klasyfikacją Ministra"). Do tego momentu do nadawanych stopni i tytułów stosowano kolejne wersje klasyfikacji dziedzinowej określonej przez Centralną Komisję do spraw Stopni i Tytułów (CK). Porównując klasyfikację CK z klasyfikacją Ministra, można zauważyć, że część dyscyplin znajdujących się w klasyfikacji CK w dziedzinie nauki humanistyczne znalazła się w klasyfikacji Ministra w nowej dziedzinie - nauki społeczne. Dziedzina ta zawiera również dziedzinę nauki wojskowe z klasyfikacji CK, ale przekształconą $\mathrm{w}$ dwie dyscypliny: nauki o bezpieczeństwie i nauki o obronności. W efekcie nie jest możliwe bezpośrednie porównywanie liczby stopni i tytułów nadawanych w poszczególnych dziedzinach zgodnie z omówionymi klasyfikacjami w kolejnych latach, gdyż w sposób istotny zmieniła się np. definicja dziedziny nauk humanistycznych.

Aby uzyskać jednolity zestaw danych dla całego badanego okresu, konieczna była dodatkowa modyfikacja znajdujących się w klasyfikacji Ministra definicji obszarów. Ze względu na zmiany klasyfikacyjne dla celów porównawczych utworzono „obszar nauk humanistycznych i społecznych” zawierający następujące dyscypliny: nauki ekonomiczne, nauki humanistyczne, nauki prawne, nauki społeczne, nauki teologiczne i nauki wojskowe. Pozostałe obszary zdefiniowane w klasyfikacji Mi-

${ }^{1}$ http://www.nauka-polska.pl/Bazy-danych.html [20.12.2016]. 
nistra można łatwo rozszerzyć na lata wcześniejsze uwzględniając stopnie i tytuły nadane w poszczególnych dyscyplinach wchodzących w skład tych obszarów.

W całej pracy zastosowano następujące oznaczenia: $\mathrm{H}$ - obszar nauk humanistycznych i społecznych, SCI - obszar nauk ścisłych, P - obszar nauk przyrodniczych, $\mathrm{T}$ - obszar nauk technicznych, $\mathrm{R}$ - obszar nauk rolniczych, leśnych i weterynaryjnych, $\mathrm{M}$ - obszar nauk medycznych i nauk o zdrowiu oraz nauk o kulturze fizycznej, SZT - obszar sztuki.

\section{Wiarygodność danych}

Dużym problemem w analizach statystycznych jest znalezienie wiarygodnego źródła danych. Jest to zadanie łatwe w przypadku istnienia jednolitego źródła danych, które rejestruje w niezmienionej formie informacje powstające rok po roku. Niestety, sprawa się komplikuje w przypadku, gdy takie źródło nie istnieje, dane są publikowane nieregularnie lub zmienia się forma i zakres rozpowszechnianych danych. Zbieranie i udostępnianie danych jednostkowych ma, w niektórych dziedzinach, w Polsce krótką tradycję, a dodatkowo dane te są niepełne i publikowane w formie uniemożliwiającej ich bezpośrednie wykorzystanie (np. jako pliki PDF).

Czynniki te zmuszają do szukania alternatywnych źródeł danych. W tym momencie pojawia się problem ich wiarygodności. Dane są tu wprowadzane albo na podstawie danych źródłowych, albo na podstawie informacji niezależnie przekazywanych przez podmioty, których te dane dotyczą lub w których powstają. We wszystkich przypadkach zachodzi prawdopodobieństwo pojawienia się błędów wynikających z niekompletności oraz niedokładności przekazywanych danych. Dlatego przeprowadzono badanie wiarygodności Bazy Wiedzy o Nauce Polskiej. Baza ta była również wykorzystywana do przygotowania danych do artykułu Kto zdobywa stopnie i tytuty naukowe - trochę statystyki, ale wówczas nie były dostępne oficjalnie publikowane dane, które mogłyby posłużyć do weryfikacji jakości znajdujących się w BWNP danych.

Aby dokonać weryfikacji, porównano pochodzące z BWNP informacje o liczbie nadanych tytułów naukowych z danymi opublikowanymi na stronie Kancelarii Prezydenta $\mathrm{RP}^{2}$. Niestety informacje o nadanych przez Prezydenta tytułach dotyczą tylko lat 2006-2015 i nie ma żadnych oficjalnych informacji dotyczących lat wcześniejszych.

Dane pochodzące z BWNP obejmują tytuły nadane w dowolnym czasie (najwcześniejsze wpisy dotyczą tytułów nadanych przed II wojną światową) i są to nie tylko tytuły nadane przez Prezydenta RP, ale również inne tytuły uznawane oficjalnie w Polsce (np. tytuły nadane w Watykanie). Dlatego też w niektórych przypad-

${ }^{2}$ http://www.prezydent.pl/aktualnosci/statystyki/statystyki-profesorskie/ [20.12.2016]. 
Wykres 1. Liczba nadanych tytułów profesora - zgodność danych pochodzących z BWNP i informacji prezentowanych na stronie internetowej Prezydenta RP

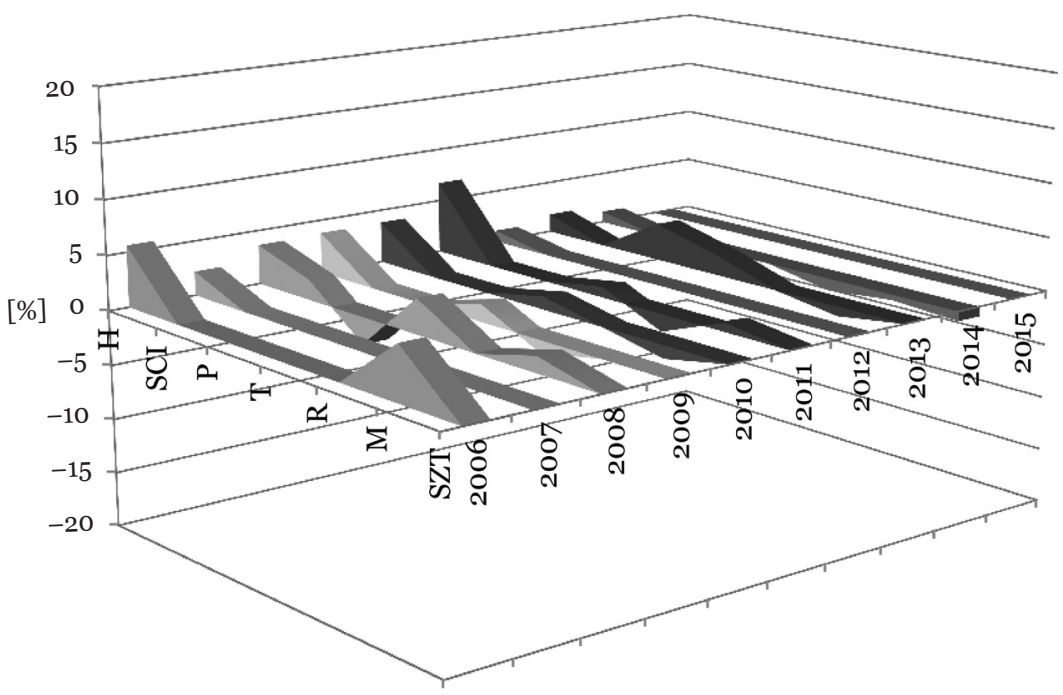

Źródło: opracowanie własne.

kach w BWNP będzie więcej tytułów, niż wynika to ze statystyk podawanych na stronie Prezydenta RP. Zgodność tę prezentuje wykres 1, gdzie dodatnia wartość oznacza, że w BWNP jest więcej informacji o nadanych tytułach.

Jak widać, w większości przypadków występuje pełna zgodność między danymi znajdującymi się w BWNP a informacją prezentowaną na stronie internetowej Prezydenta - rozbieżność sięga zaledwie kilku procent. W świetle tego można uznać, że dane z BWNP są w pełni wiarygodne w zakresie informacji o nadanych tytułach naukowych.

Nieco gorzej wygląda sytuacja, gdy rozpatrzymy zgodność BWNP ze stanem faktycznym nadanych stopni naukowych. W tym przypadku nie ma jednego centralnego urzędu, który nadaje stopnie naukowe. Stopnie nadawane są przez jednostki posiadające uprawnienia do ich nadawania - uprawnienia te przyznawane są jednostkom przez Centralną Komisję do spraw Stopni i Tytułów. Na mocy ustawy o stopniach naukowych i tytule naukowym oraz o stopniach i tytule w zakresie sztuki jednostki są zobowiązane do raportowania nadanych stopni do bazy prowadzonej przez ministra właściwego do spraw nauki. Niestety obowiązek ten istnieje dopiero od $2011 \mathrm{r}$. Minister w każdym roku publikuje wykaz nadanych w roku poprzednim stopni naukowych, przy czym - jak łatwo się domyślić - dostępne są tylko dane za lata 2011-2014. Porównanie zgodności liczby nadanych stopni zaczerpniętej z BWNP i wspomnianych list prezentują wykresy 2 i 3. 
Wykres 2. Zgodność liczby nadanych stopni doktora habilitowanego dla danych pochodzących z BWNP i informacji podawanych w komunikatach Ministra

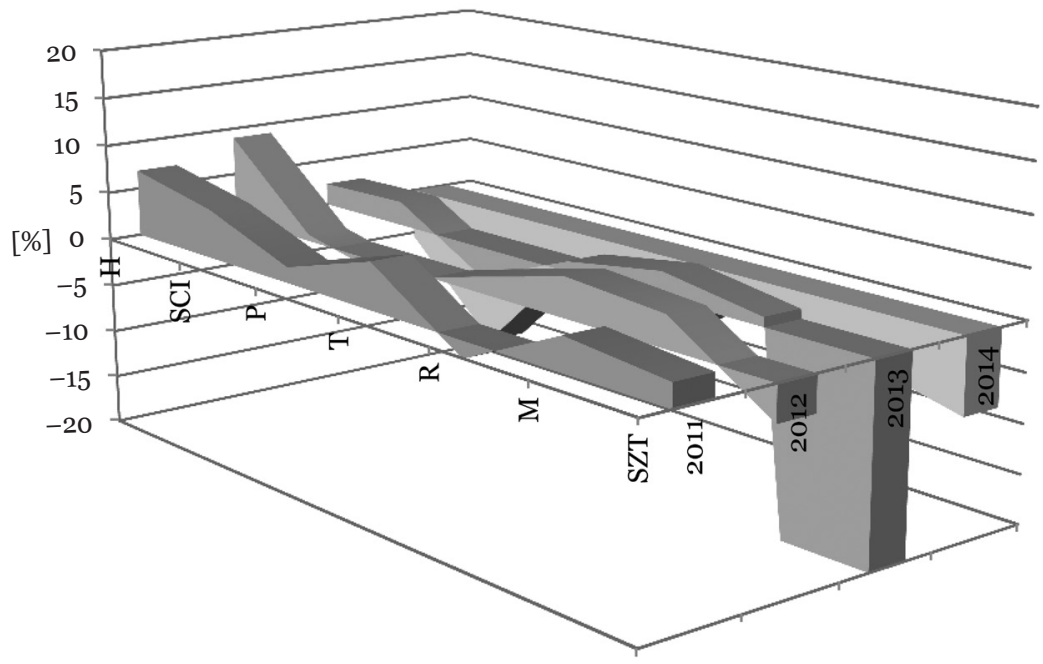

Źródło: opracowanie własne.

Wykres 3. Liczba nadanych stopni doktora dla danych pochodzących z BWNP i informacji podawanych w komunikatach Ministra

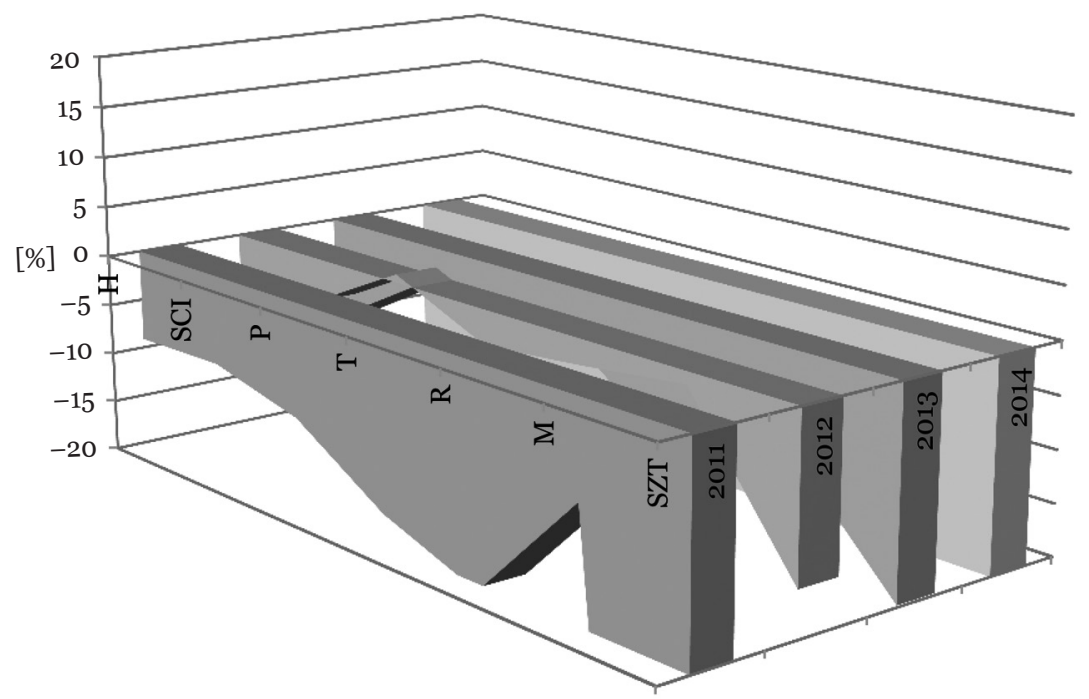

Źródło: opracowanie własne. 
W przypadku wykazu stopni doktora habilitowanego zgodność można uznać za zadowalającą, gdyż zdecydowana większość rozbieżności jest na poziomie kilku procent - tylko w obszarze sztuki wyraźnie brakuje w BWNP informacji o stopniach nadanych w $2013 \mathrm{r}$.

Dla stopni doktora sytuacja wygląda znacznie gorzej. W kilku przypadkach obserwujemy ponad 20-proc. rozbieżności - dotyczy to głównie obszaru sztuki, dlatego też dane dla tego obszaru nie będą dalej szczegółowo analizowane.

\subsection{Stopień naukowy doktora}

Jak pokazano na wykresie 4, liczba uzyskiwanych stopni doktora zależy nie tylko od obszaru wiedzy, ale również od roku, w którym stopień został nadany. Ponieważ liczba nadanych stopni zmienia się w sposób skokowy, w analizie posługiwać się będziemy trendami - do analizy wybrano trend liniowy.

W badanym okresie najwięcej stopni doktora nadano w obszarze nauk humanistycznych i społecznych - prawie dwa razy więcej niż w drugim w kolejności obszarze nauk medycznych i nauk o zdrowiu oraz nauk o kulturze fizycznej. Średnia liczba nadanych stopni od $2007 \mathrm{r}$. w obszarze nauk humanistycznych i społecznych jest na poziomie 2000 i obserwuje się wyraźny trend wzrostowy o współczynniku wzrostu około 24 stopni/rok, podczas gdy w obszarze nauk medycznych i nauk

Wykres 4. Liczba nadanych stopni doktora w kolejnych latach ogółem w podziale na obszary nauki i sztuki

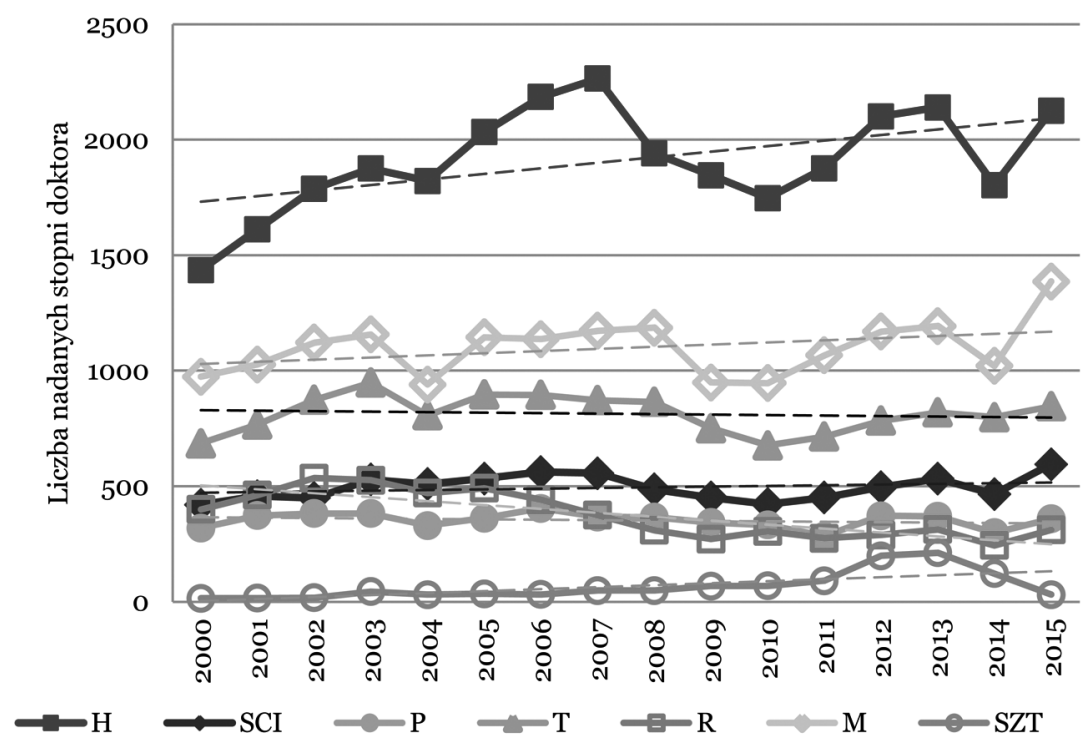

Źródło: opracowanie własne. 
o zdrowiu oraz nauk o kulturze fizycznej jest on na poziomie 1100 stopni i wykazuje znacznie słabszy (ale drugi co do wielkości) trend wzrostowy - o współczynniku wzrostu około 9 stopni/rok. Wyróżnia się jeszcze obszar nauk technicznych, gdzie liczba nadanych stopni w całym okresie przekracza 500, ale w tym przypadku obserwujemy wyraźny trend spadkowy o współczynniku spadku około 2 stopni/rok. Trendy wzrostowe obserwujemy jeszcze w obszarze sztuki oraz obszarze nauk ścisłych, natomiast trendy spadkowe - w obszarze nauk przyrodniczych i obszarze nauk rolniczych, leśnych i weterynaryjnych.

Podsumowując: najwięcej stopni doktora nadano w obszarze nauk humanistycznych i społecznych i liczba ich systematycznie rośnie, zaś liczba stopni nadanych w obszarach nauk przyrodniczych, nauk technicznych i nauk rolniczych, leśnych i weterynaryjnych systematycznie maleje. Obserwujemy tu więc trendy odwrotne niż te, które istnieją w nauce światowej, gdzie odchodzi się od kształcenia w zakresie nauk humanistycznych na rzecz nauk ścisłych i inżynierskich.

Zasadniczo liczba nadanych stopni doktora powinna istotnie zależeć od liczby doktorantów - oczywiście z pewnym przesunięciem czasowym, gdyż doktorant musi najpierw ukończyć studia (z reguły czteroletnie), a dopiero potem uzyskać stopień. Zestawienie liczby doktorantów, opracowane na podstawie danych GUS, prezentuje np. Dorota Jegorow (2014). Dane te przedstawiono również na wykresie 5. Jak widać, w latach 1999-2012 liczba doktorantów prawie się podwoiła. Popatrzmy więc, czy miało to jakieś przełożenie na liczbę nadanych stopni w okresie następującym po tych latach - dane te przedstawia wykres 6 .

Wykres 5. Liczba doktorantów

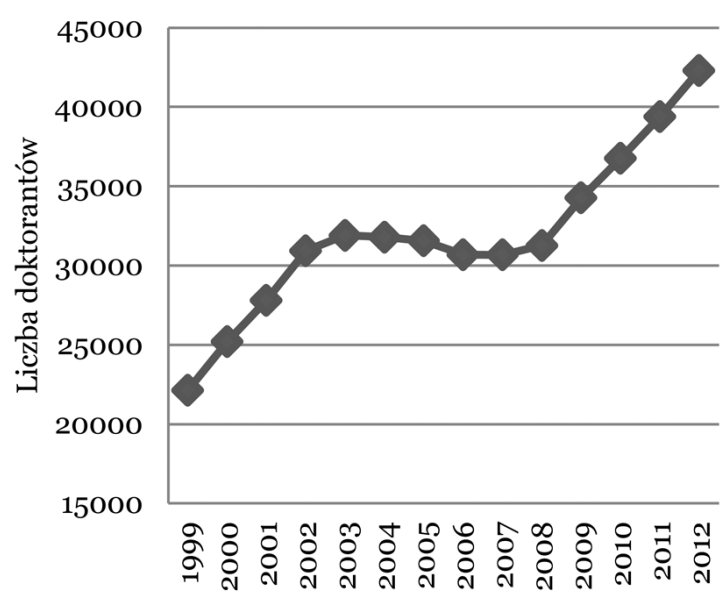

Źródło: opracowanie na podstawie Jegorow 2014. 
Wykres 6. Liczba stopni doktora nadanych w kolejnych latach

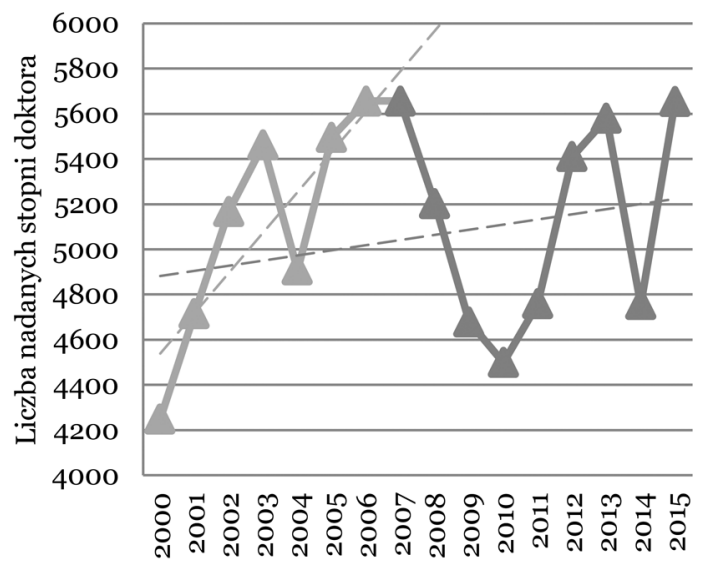

Źródło: opracowanie własne.

Można tu zauważyć dwa wyraźne trendy: 1) w latach 1999-2003 widać gwałtowny wzrost liczby nadawanych stopni doktora - w ciągu tych 7 lat liczba stopni wzrosła o ponad 30\%; 2) od 2006 r. (czyli w ciągu ostatnich 10 lat) średnia liczba uzyskiwanych stopni praktycznie się nie zmienia. Zatem gwałtowny wzrost liczby doktorantów w latach 1999-2002 odpowiada wzrostowi liczby uzyskanych stopni doktora w latach 2000-2006. Natomiast drugiemu wzrostowi liczby doktorantów, który nastąpił w latach 2008-2012, nie towarzyszy wzrost liczby nadawanych w latach 2012-2015 stopni. Z powyższej obserwacji można wysnuć jeden wniosek: w odniesieniu do lat 1999-2005 efektywność studiów doktoranckich w latach 2005-2015 okresie gwałtownie spadła. Nie mamy niestety danych, które ukazywałyby liczbę stopni uzyskanych przez osoby, które wcześniej były doktorantami, a trzeba pamiętać, że doktoraty uzyskują nie tylko osoby biorące udział w studiach doktoranckich, ale również inne. Możliwe jest też to, że w latach 2005-2015 gwałtownie wzrósł - w stosunku do liczby takich osób w latach 2000-2006 - odsetek osób uczestniczących w studiach doktoranckich, którym następnie nadano stopień doktora.

Sprawdźmy, kto częściej uzyskuje w naszym kraju stopień doktora: mężczyźni czy kobiety? Liczbę uzyskanych stopni w poszczególnych latach przedstawia wykres 7. Widać tu trend rosnący dla liczby stopni uzyskiwanych przez kobiety oraz malejący dla liczby stopni uzyskiwanych przez mężczyzn. Bezpośrednio przekłada się to na liczbę uzyskanych stopni - w latach 2000-2004 więcej stopni uzyskiwali mężczyźni, a od 2008 r. więcej kobiet uzyskuje stopień doktora.

Na wykresie 8 widać procentowy udział mężczyzn i kobiet w grupie osób, które uzyskały stopień doktora w danym roku. Jak należało się spodziewać, wykres ten 
Wykres 7. Liczba nadanych stopni doktora w danym roku

w podziale według płci osoby, której nadano stopień

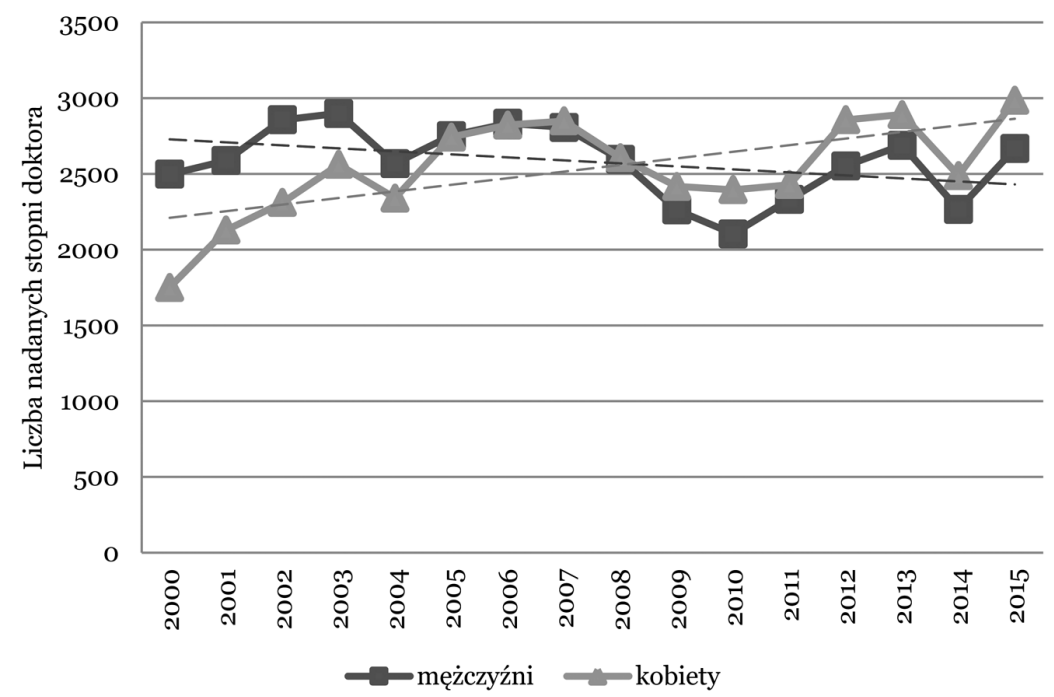

Źródło: opracowanie własne.

Wykres 8. Udział procentowy w liczbie nadanych stopni doktora w kolejnych latach w zależności od płci osoby, która uzyskała stopień

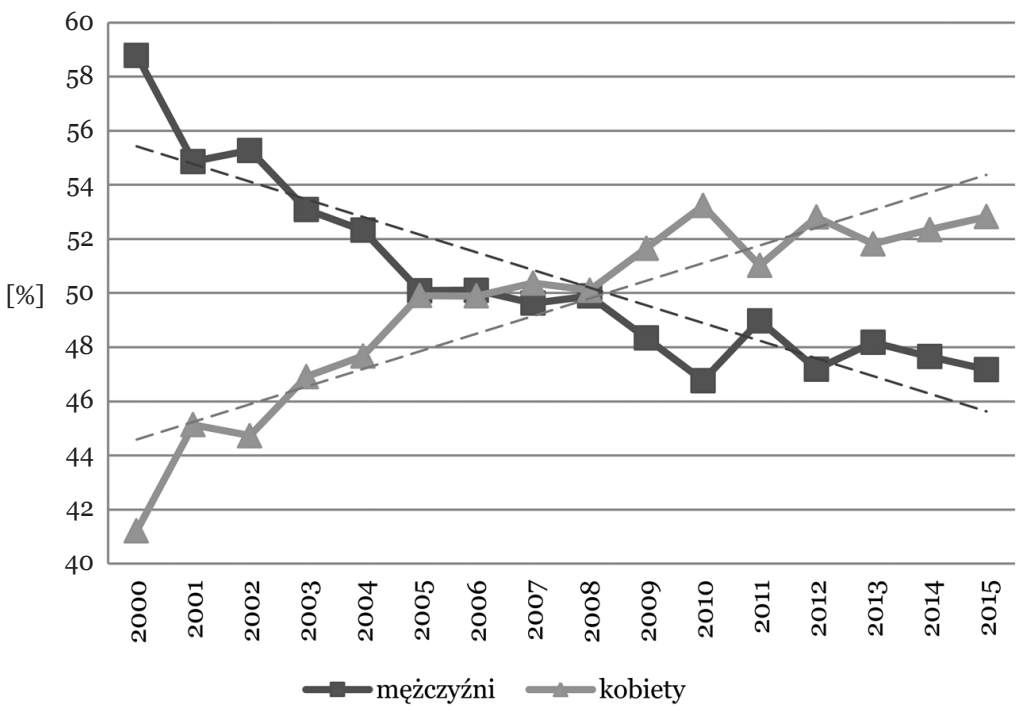

Źródło: opracowanie własne. 
uwypukla efekty, które można było zauważyć na wykresie 7: do 2004 r. znacznie więcej mężczyzn niż kobiet uzyskiwało stopień doktora, w latach 2005-2008 nastąpiło wyrównanie proporcji osób różnej płci, a od 2009 r. widać zdecydowaną przewagę kobiet wśród osób, które uzyskały stopień doktora.

Tendencję wzrostu liczby kobiet uzyskujących stopień naukowy doktora oraz tendencję spadku liczby stopni uzyskiwanych przez mężczyzn można również zaobserwować na wykresie 9, gdzie pokazano, jak zmieniała się liczba nadanych stopni doktora w kolejnych latach w stosunku do liczby stopni nadanych w 2000 r.

Wykres 9. Procentowa zmiana liczby nadanych stopni doktora w kolejnych latach w odniesieniu do liczby stopni nadanych osobom tej samej płci w 2000 r.

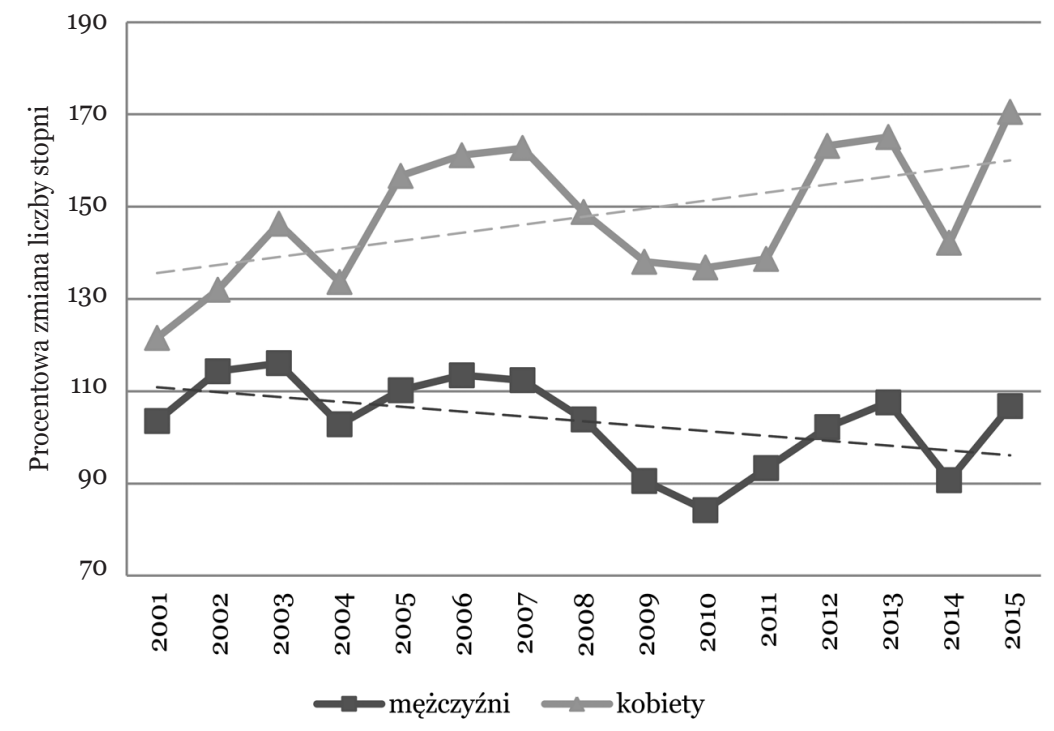

Źródło: opracowanie własne.

Wykres ten lepiej obrazuje rzeczywisty charakter zmian liczby uzyskiwanych stopni niż wykres udziału procentowego osób obu płci, który musi być symetryczny względem linii 50\%.

Na podstawie zaprezentowanych wyników można sformułować wniosek, że procentowy udział liczby kobiet w liczbie osób uzyskujących stopień doktora w Polsce, w ostatnich latach, systematycznie rośnie.

Takie są tendencje ogólne, jednak liczba uzyskanych doktoratów, co nie dziwi, silnie zależy od obszaru nauki którego dotyczy. Na wykresach 10-15 przedstawiono procentową zmianę liczby nadanych stopni doktora w kolejnych latach w zależności od płci w odniesieniu do liczby stopni nadanych w $2000 \mathrm{r}$. w poszczególnych obszarach nauki. 
Wykres 10. Procentowa zmiana liczby nadanych stopni doktora obszar nauk humanistycznych i społecznych

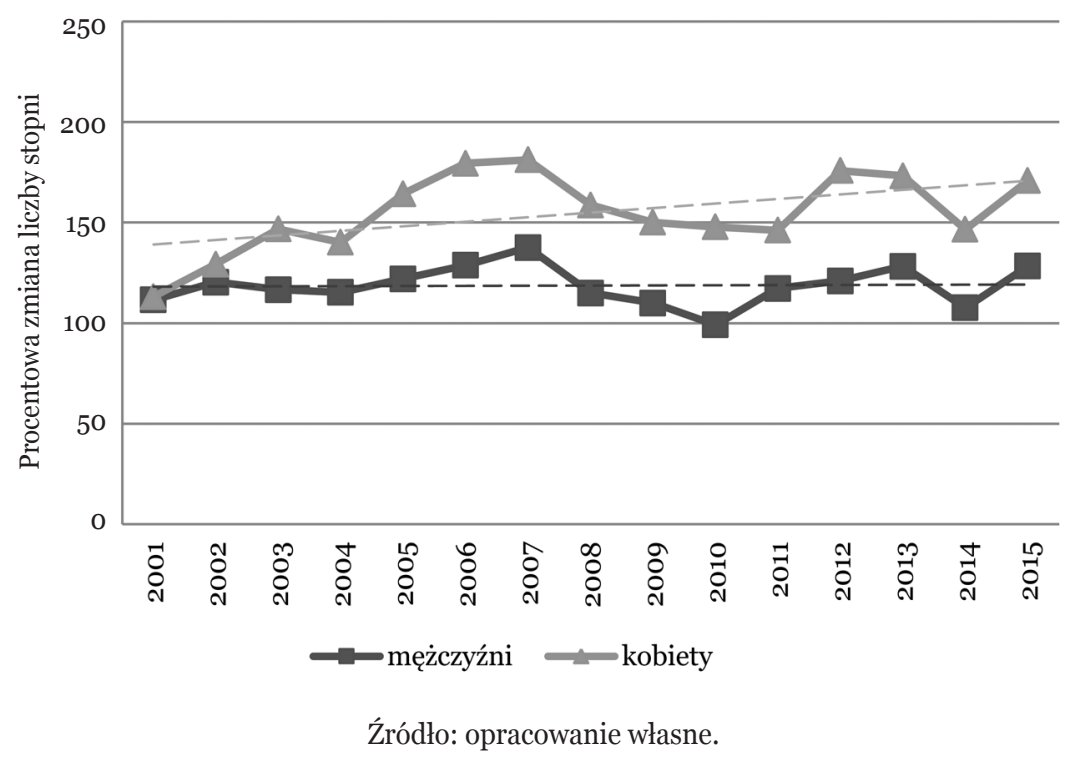

Wykres 11. Procentowa zmiana liczby nadanych stopni doktora obszar nauk ścisłych

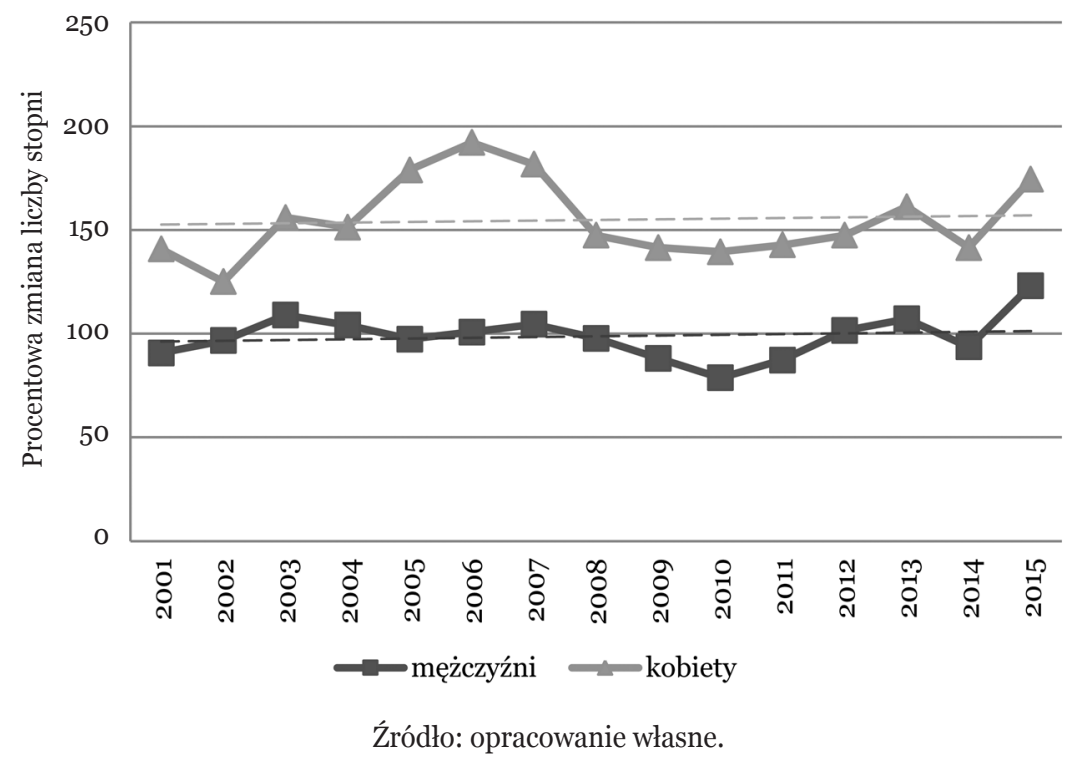


Wykres 12. Procentowa zmiana liczby nadanych stopni doktora obszar nauk przyrodniczych

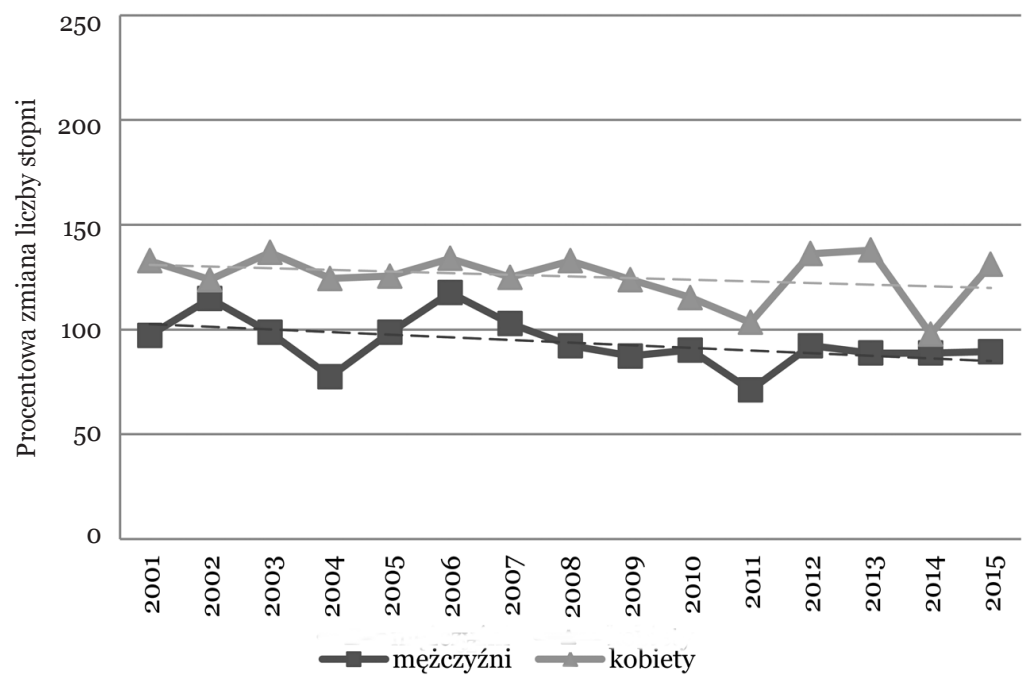

Źródło: opracowanie własne.

Wykres 13. Procentowa zmiana liczby nadanych stopni doktora obszar nauk technicznych

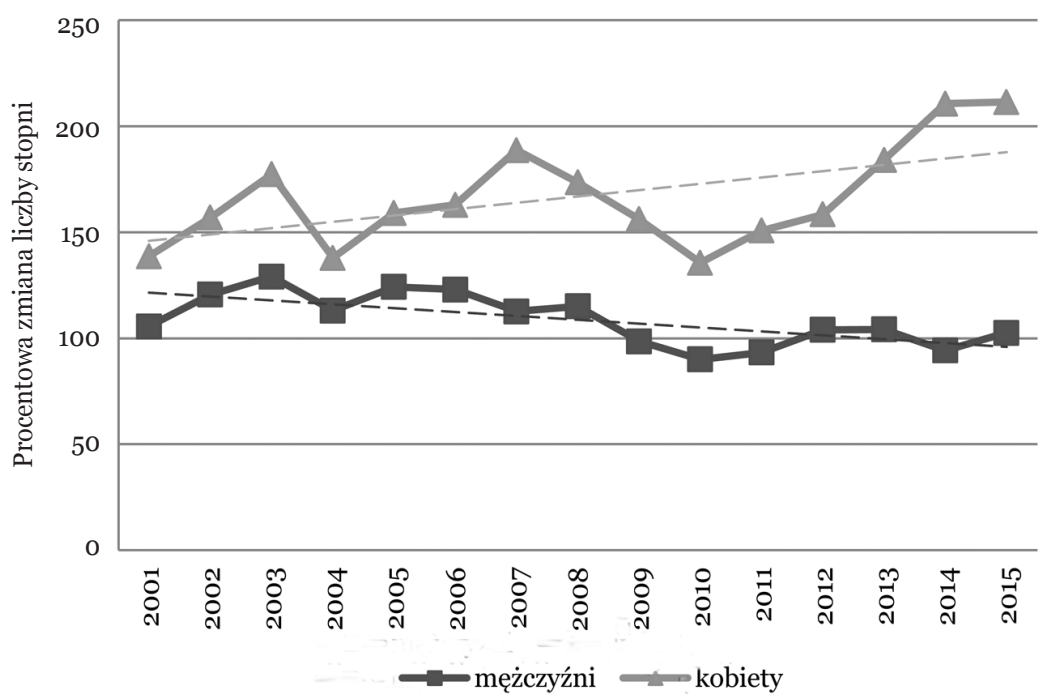

Źródło: opracowanie własne. 
Wykres 14. Procentowa zmiana liczby nadanych stopni doktora obszar nauk rolniczych, leśnych i weterynaryjnych

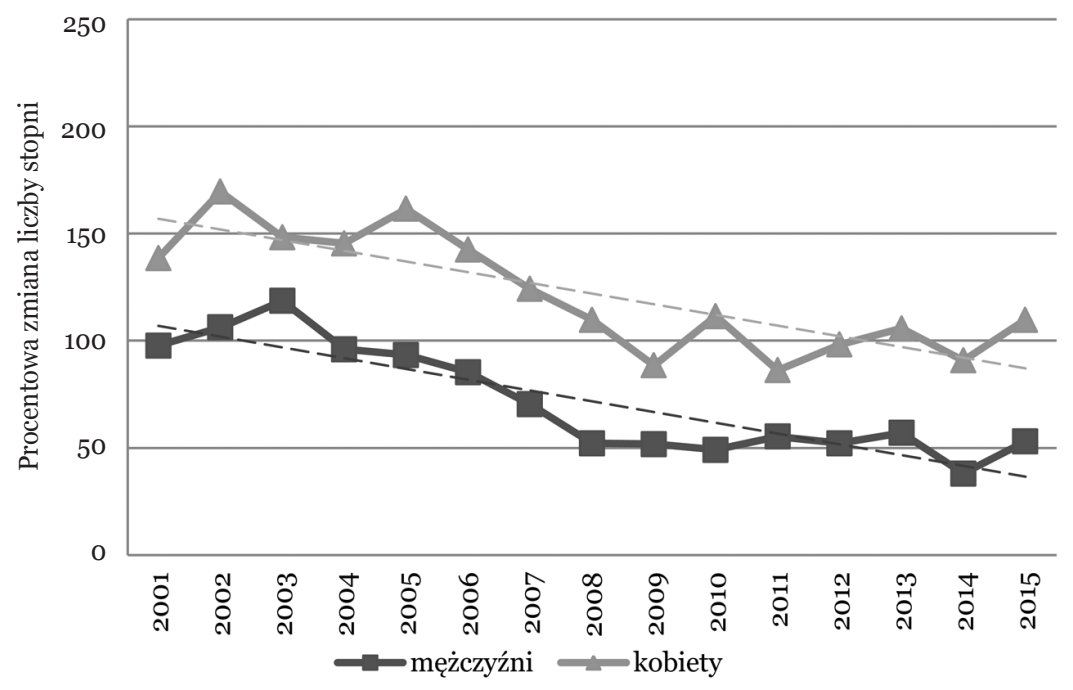

Źródło: opracowanie własne.

Wykres 15. Procentowa zmiana liczby nadanych stopni doktora obszar nauk medycznych i nauk o zdrowiu oraz nauk o kulturze fizycznej

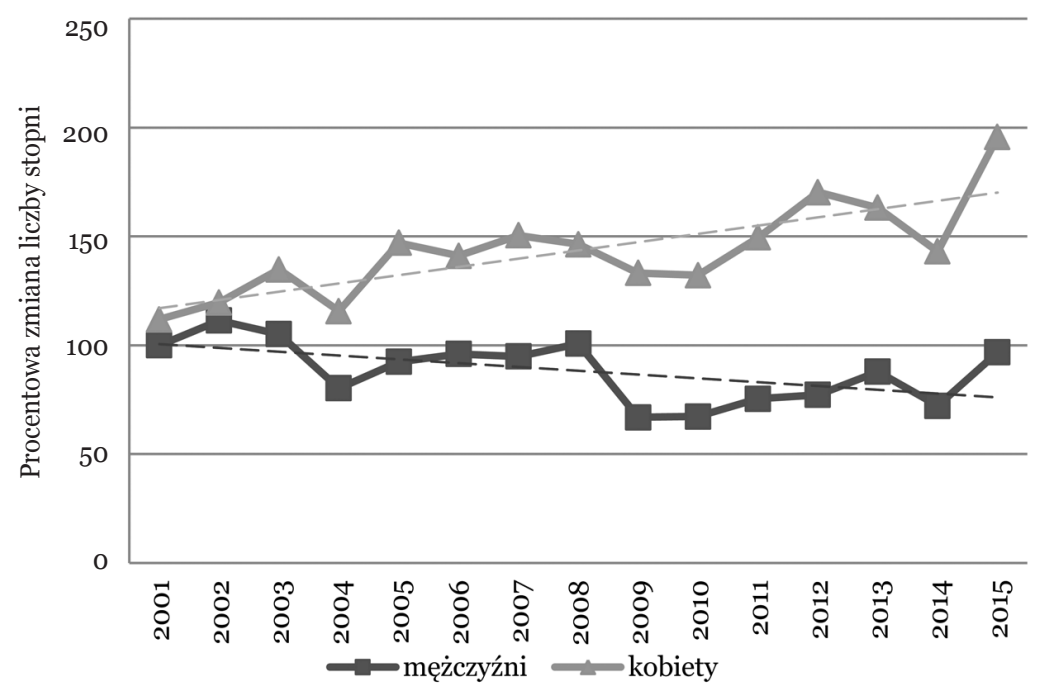

Źródło: opracowanie własne. 
Jak można zauważyć, analizując te wykresy, tylko w obszarze nauk ścisłych obserwuje się niewielki wzrost liczby mężczyzn uzyskujących stopień doktora, w obszarze nauk humanistycznych i społecznych liczba uzyskiwanych przez mężczyzn stopni doktora jest ustabilizowana, natomiast w pozostałych obszarach obserwuje się spadek tej liczby, przy czym największy spadek widoczny jest w obszarze nauk rolniczych, leśnych i weterynaryjnych. Inaczej sytuacja wygląda w przypadku liczby kobiet, którym nadano stopień doktora - tylko w obszarze nauk przyrodniczych i obszarze nauk rolniczych, leśnych i weterynaryjnych obserwuje się spadek liczby uzyskanych przez kobiety stopni. W pozostałych obszarach widać wyraźny wzrost. Największy wzrost występuje w obszarze nauk medycznych i nauk o zdrowiu oraz nauk o kulturze fizycznej - co nie dziwi, ale na drugim miejscu pod względem przyrostu liczby kobiet uzyskujących stopień doktora znajduje się obszar nauk technicznych.

Jak widać, niemal zamknięty dotąd dla kobiet obszar nauk technicznych jest obecnie coraz bardziej przez nie dominowany - zwłaszcza że liczba stopni doktora uzyskiwanych przez mężczyzn w tym obszarze systematycznie spada.

Zobaczmy teraz, jak kształtuje się struktura stopni pod względem wieku, jaki dana osoba miała w chwili uzyskania stopnia. W artykule Kto zdobywa stopnie i tytuly naukowe - trochę statystyki (Rodzik 2009) pokazano, że stopnie doktora uzyskiwane były głównie przez osoby młode, które nie ukończyły 35. roku życia, przy czym udział procentowy nadanych stopni wykazywał tendencję do stabilizacji zarówno w przypadku mężczyzn, jak i kobiet. Zobaczmy, czy trend ten utrzymał się również w kolejnych latach (2009-2015).

Na wykresach 16 i 17 pokazano udział procentowy nadanych stopni doktora $\mathrm{w}$ podziale na grupy wiekowe $\mathrm{w}$ ramach jednej płci. Zdecydowanie przeważają osoby młode, poniżej 35. roku życia, przy czym w przypadku doktoratów uzyskiwanych przez kobiety widać wyraźnie trend rosnący, podobnie jest w przypadku stopnia uzyskiwanego przez mężczyzn, przy czym trend wykazuje tu nieco mniejszy wzrost. Natomiast odsetek stopni uzyskiwanych przez osoby mające więcej niż 35 lat w każdym przypadku wykazuje nieznaczną, ale wyraźną tendencję spadkową.

Można wobec tego rozszerzyć poprzednio sformułowany wniosek: wyraźnie rośnie liczba doktoratów uzyskiwanych przez osoby młode - poniżej 35. roku życia, podczas gdy liczba stopni doktora uzyskiwanych przez osoby w wieku 35-44 lat wykazuje tendencję spadkową.

Warto także zwrócić uwagę na kompletność danych znajdujących się w BWNP. Według danych przedstawionych w poprzednio wspomnianym artykule (Rodzik 2009) odsetek osób, dla których nie był znany wiek, w przypadku doktoratów nadanych w latach 2005-2008 utrzymywał się (zarówno dla kobiet, jak i dla mężczyzn) na poziomie $20 \%$. W prezentowanych obecnie danych, dla tego samego okresu, liczba stopni nadanych osobom o nieokreślonym wieku jest na poziomie 10\%, czyli 
Wykres 16. Udział procentowy w liczbie nadanych stopni doktora

w zależności od wieku, w jakim uzyskiwano stopień - kobiety

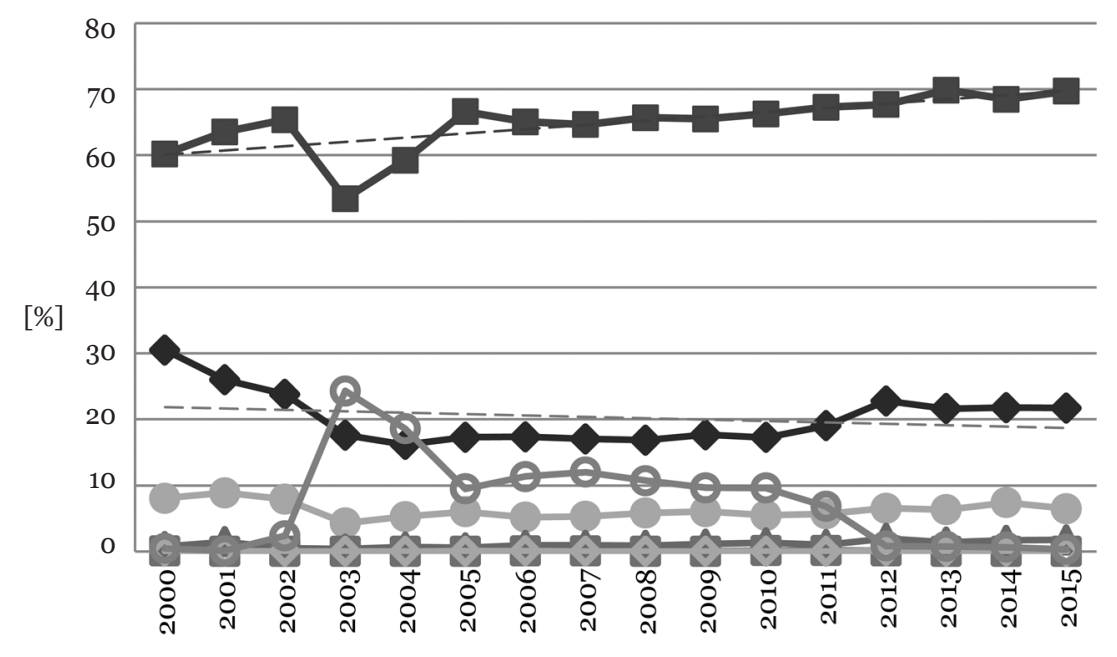

$\longrightarrow<35-35-44-45-54-55-64-65-69-70>-$ nieokresilony

Źródło: opracowanie własne.

Wykres 17. Udział procentowy w liczbie nadanych stopni doktora

w zależności od wieku, w jakim uzyskiwano stopień - mężczyźni

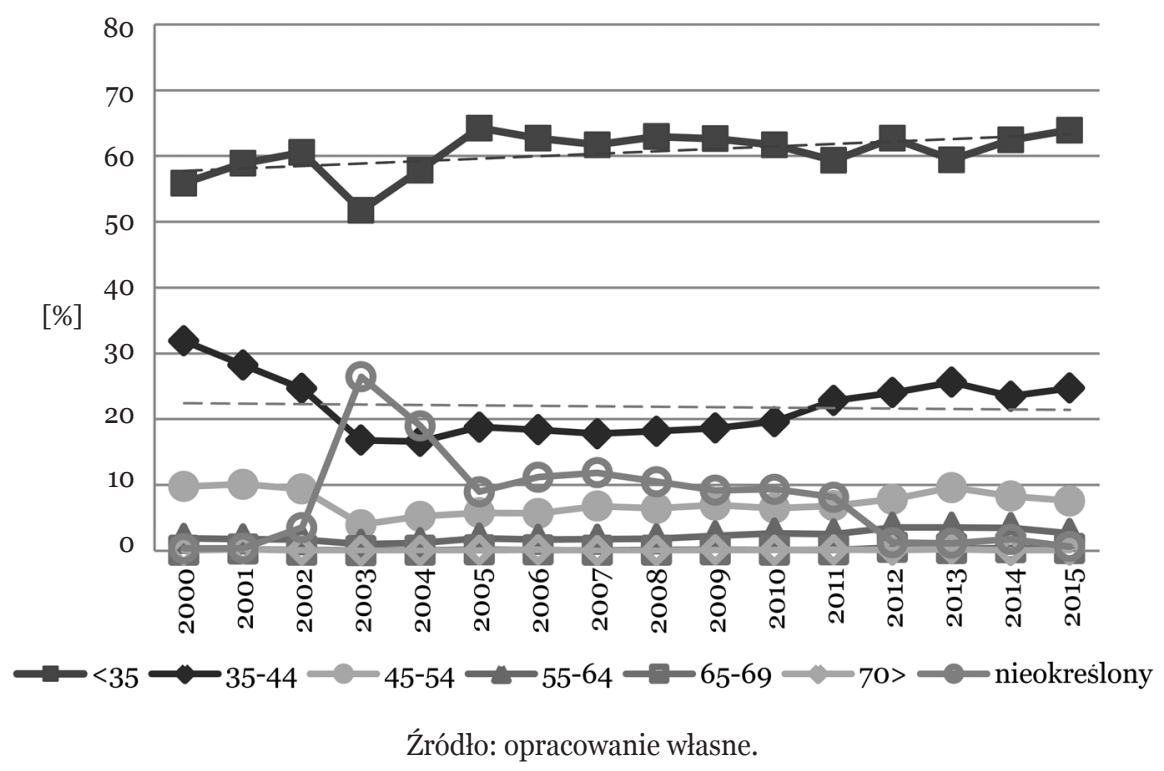


dane zostały uzupełnione, natomiast od 2012 r. spadła poniżej 2\% dla mężczyzn i poniżej $1 \%$ dla kobiet.

\subsection{Stopień naukowy doktora habilitowanego lub doktora habilitowanego sztuki}

Habilitacja od lat jest przedmiotem sporów w środowisku naukowym. Jedni uważają ją za przeżytek i wnioskują o jej usunięcie, inni zawzięcie jej bronią. W $2008 \mathrm{r}$. przygotowano nawet projekt reformy systemu stopni naukowych, który przewidywał m.in. zniesienie habilitacji, ale w wyniku protestów części środowiska naukowego projekt został zarzucony.

Wykres 18. Zależność liczby nadanych stopni doktora habilitowanego od roku

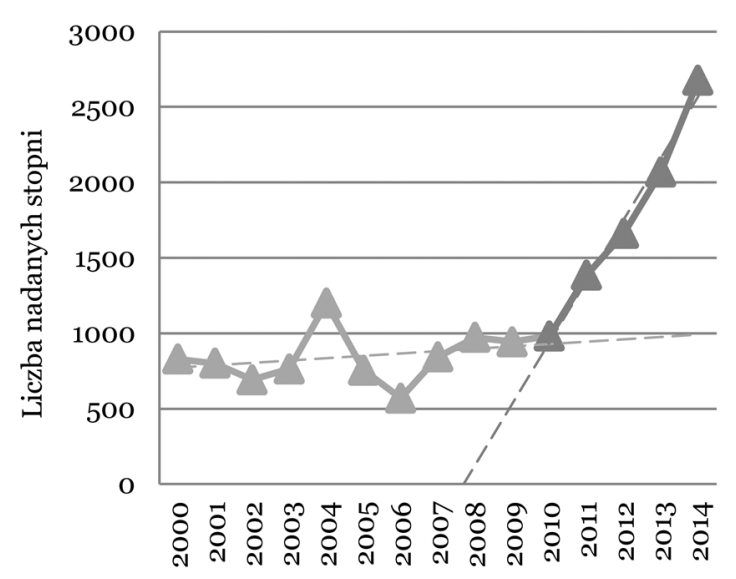

Źródło: opracowanie własne.

Zobaczmy zatem, czy stopień ten jest popularny. Warto podkreślić, że posiadanie tego stopnia (lub posiadanie uprawnien z nim równoważnych nabytych na podstawie art. 21a ustawy) jest warunkiem dalszego awansu naukowego, czyli uzyskania tytułu profesora. Uzyskanie habilitacji jest również konieczne ze względu na spełnienie wymogów zatrudnienia w niektórych jednostkach naukowych na określonych stanowiskach (np. dla jednostek PAN).

Na wykresie 18 widać zależność liczby habilitacji od roku jej uzyskania. Tak jak w przypadku doktoratów obserwuje się tu dwa trendy. Są one jednak całkowicie odmienne od tych, które obserwujemy dla doktoratów. O ile największy wzrost liczby nadanych stopni doktora obserwuje się w latach 2000-2006, o tyle w tym czasie (a właściwie aż do 2010 r.), liczba nadawanych stopni doktora habilitowanego jest 
w zasadzie stała i nie przekracza 1000 stopni nadawanych rocznie. Po 2010 r. liczba ta gwałtownie rośnie - od 2010 do 2014 r. wzrost był ponad 2,5-krotny - z 982 habilitacji w 2010 r. do 2676 w 2014 r.

Wykres 19. Zależność liczby nadanych w danym roku stopni doktora habilitowanego od obszaru nauk, w którym stopień został nadany

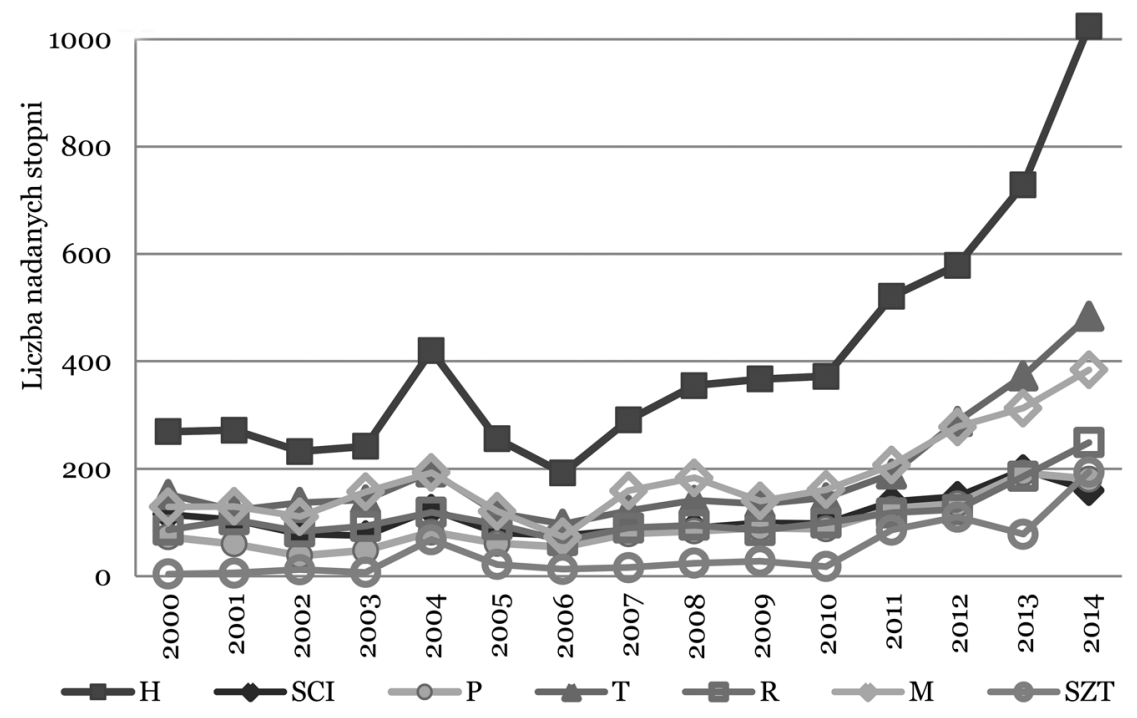

Źródło: opracowanie własne.

Zwróćmy uwagę na to, że w 2010 roku znowelizowano dwie ustawy: o PAN oraz o szkolnictwie wyższym. W obu tych nowelizacjach wprowadzono ograniczenie okresu zatrudnienia dla osób nierealizujących procesu awansu naukowego. Z założenia zapisy te miały mobilizować pracowników naukowych posiadających stopień doktora do możliwie szybkiego uzyskania kolejnego stopnia - doktora habilitowanego. Patrząc na przedstawione wyniki, można stwierdzić, że zamierzenie to zostało zrealizowane liczba stopni doktora habilitowanego lawinowo wzrosła po wprowadzeniu w życie nowych zapisów. Czy i jak wpłynęło to na wiek osób uzyskujących tytuł naukowy, zobaczymy w dalszej części artykułu.

Sprawdźmy, czy gwałtowny wzrost liczby habilitacji, jaki nastąpił po 2010 r., dotyczy wszystkich obszarów nauki. Wyniki tej analizy przedstawiono na wykresie 19.

$\mathrm{Na}$ ich podstawie można jednoznacznie stwierdzić, że prawie we wszystkich obszarach w okresie 2000-2010 liczba habilitacji jest praktycznie stała. Wyjątek stanowi obszar nauk humanistycznych i społecznych, gdzie zanotowano prawie 40proc. wzrost liczby habilitacji (z 269 w 2000 r. do 372 w 2010 r.). Natomiast od 
2010 r. liczba uzyskanych habilitacji gwałtownie rośnie w każdym obszarze, przy czym największą dynamiką cechuje się obszar nauk humanistycznych i społecznych (1024 nadane stopnie w 2014 r. wobec 372 stopni nadanych w 2010 r.).

Odnosząc te spostrzeżenia do tego, co zaobserwowano dla stopni doktora, można sformułować regułę zgodną z poprzednią obserwacją: najwięcej stopni doktora habilitowanego nadawanych jest w obszarze nauk humanistycznych i społecznych i liczba ich systematycznie rośnie.

Warto odnotować, że w obszarze nauk medycznych i nauk o zdrowiu oraz nauk o kulturze fizycznej, który znalazł się na drugim miejscu pod względem nadanych stopni doktora, liczba habilitacji jest mniejsza niż w obszarze nauk technicznych, czyli przedstawiciele nauk technicznych znacznie częściej kontynuują swoją karierę naukową (uzyskując habilitację) niż osoby reprezentujące obszar nauk medycznych i nauk o zdrowiu oraz nauk o kulturze fizycznej.

Sprawdźmy teraz, jak wyglądają proporcje osób różnej płci uzyskujących stopień doktora habilitowanego. Takie porównanie zawiera wykres 20. Analizując przedstawione dane, od razu można zauważyć, że mężczyźni uzyskują systematycznie więcej stopni doktora habilitowanego niż kobiety w całym badanym okresie. Różnica w liczbie uzyskiwanych stopni jest praktycznie

Wykres 20. Zależność liczby nadanych w danym roku stopni doktora habilitowanego od płci

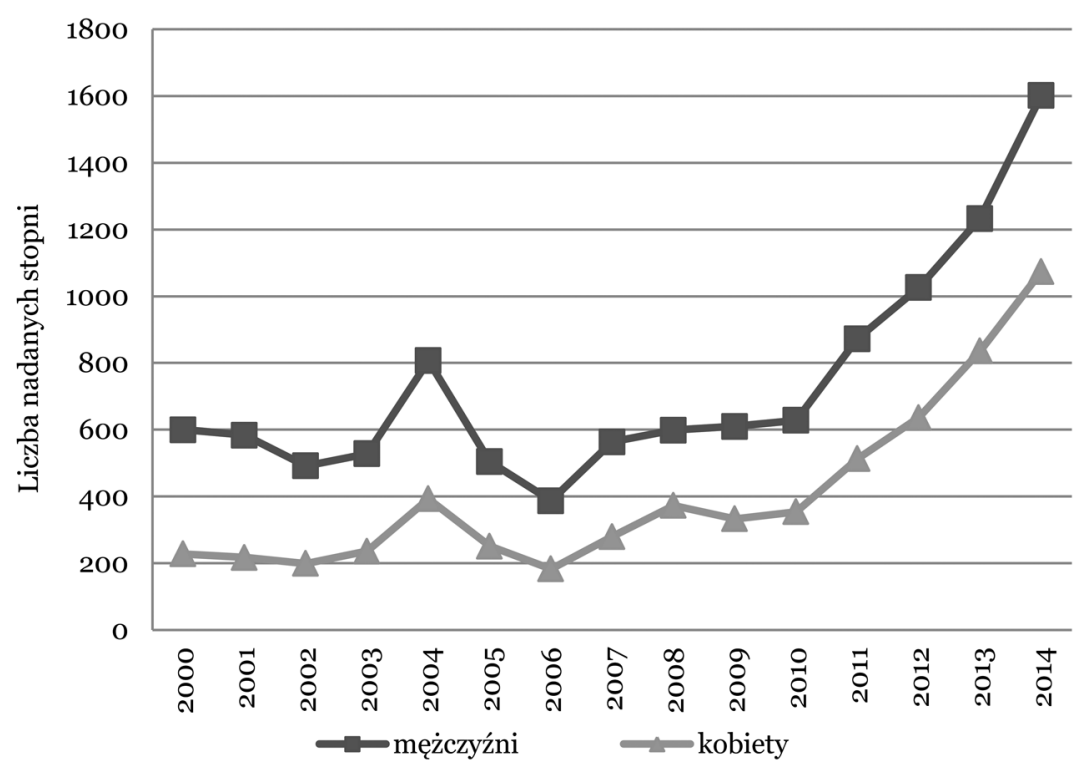

Źródło: opracowanie własne. 
stała, a znaczny wzrost liczby uzyskiwanych stopni, jaki pojawił się w ostatnich latach, dotyczy zarówno stopni uzyskiwanych przez mężczyzn, jak i przez kobiety.

Jeżeli jednak porównamy procentowy wzrost liczby uzyskiwanych stopni doktora habilitowanego (wykres 21), to zobaczymy większą (a od 2010 r. wyraźnie większą) dynamikę wzrostu liczby stopni zdobywanych przez kobiety - w 2014 r. stopień doktora habilitowanego uzyskało o 370\% więcej kobiet niż w 2000 r., podczas gdy dla tego samego okresu wzrost liczby mężczyzn wyniósł tylko około 170\%.

Wykres 21. Procentowa zmiana liczby nadanych stopni doktora habilitowanego w kolejnych latach w zależności od płci w odniesieniu do liczby stopni nadanych w $2000 \mathrm{r}$.

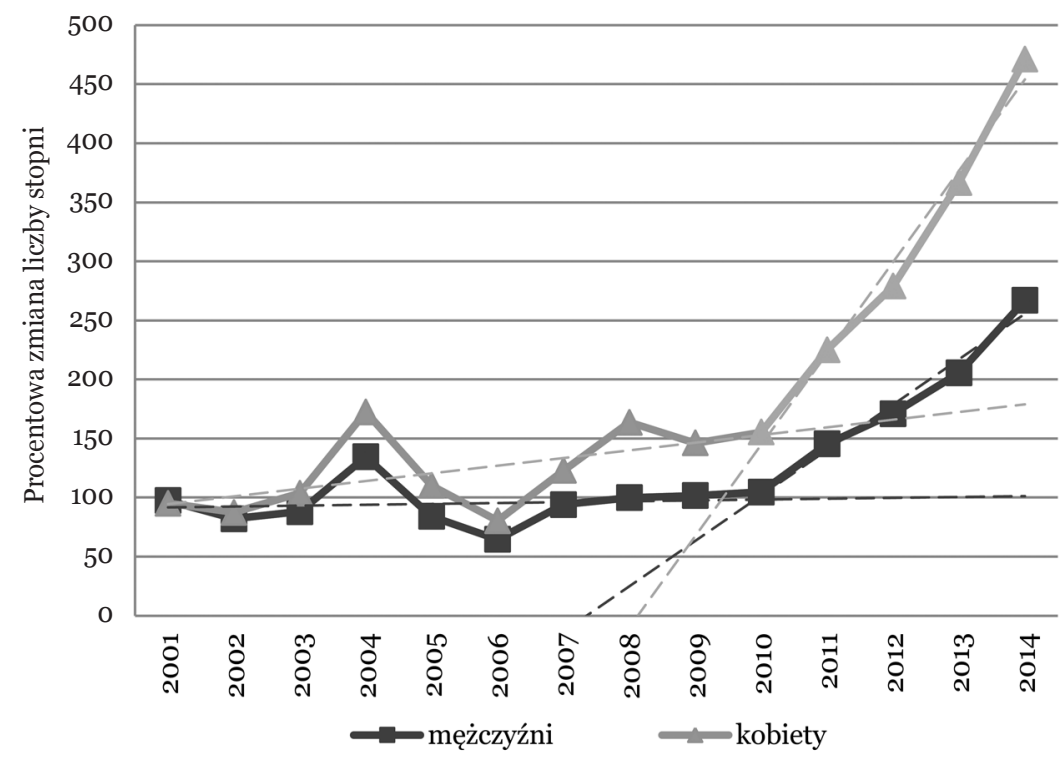

Źródło: opracowanie własne.

Znając ogólny trend uzyskiwania habilitacji pośród płci, sprawdźmy, jak wygląda rozkład w kolejnych obszarach nauki i sztuki. Obrazują to wykresy 22-28.

Nie dla wszystkich obszarów nauki obserwuje się jednakową dynamikę przyrostu liczby habilitacji. Największą dynamiką charakteryzują się obszary: nauk humanistycznych i społecznych oraz nauk technicznych, a najmniejszą - obszar nauk ścisłych, gdzie liczba mężczyzn uzyskujących stopień doktora habilitowanego jest prawie stała. Wyjątkiem jest tu obszar sztuki, gdzie procentowa zmiana co prawda sięga tysięcy - wynika to prawdopodobnie z konieczności podporządkowania się przepisom wprowadzonym w 2010 r., ale całkowita liczba uzyskanych stopni nie przekracza 200, przy czym w 2000 r. wyniosła ona zaledwie 4 (tyle zgłoszono do BWNP). 
Wykres 22. Procentowa zmiana liczby nadanych stopni doktora habilitowanego obszar nauk humanistycznych i społecznych

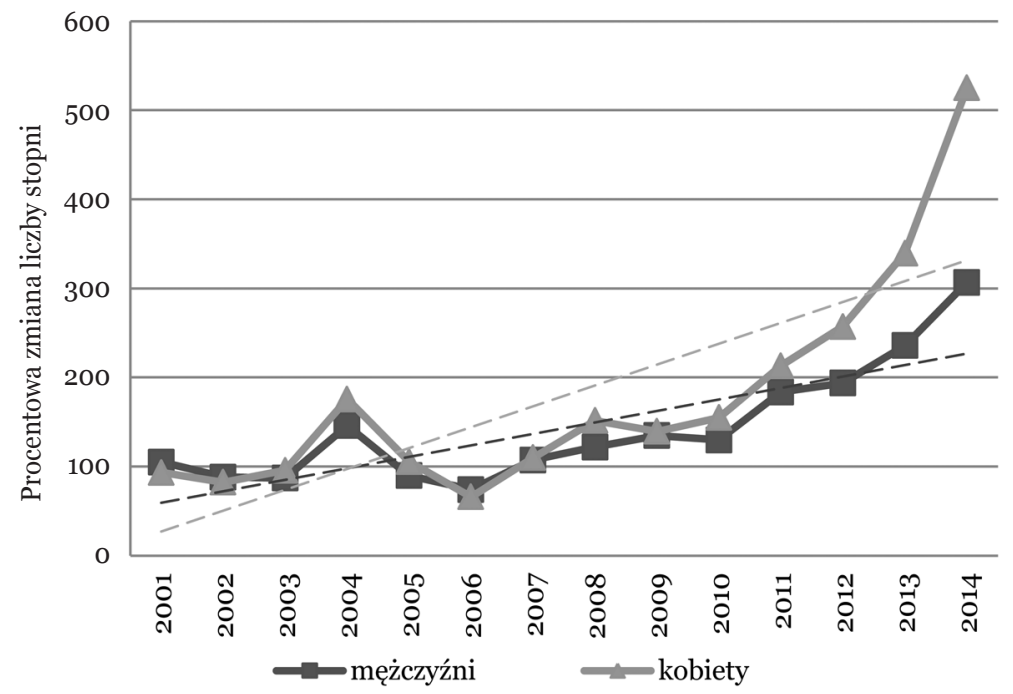

Źródło: opracowanie własne.

Wykres 23. Procentowa zmiana liczby nadanych stopni doktora habilitowanego obszar nauk ścisłych

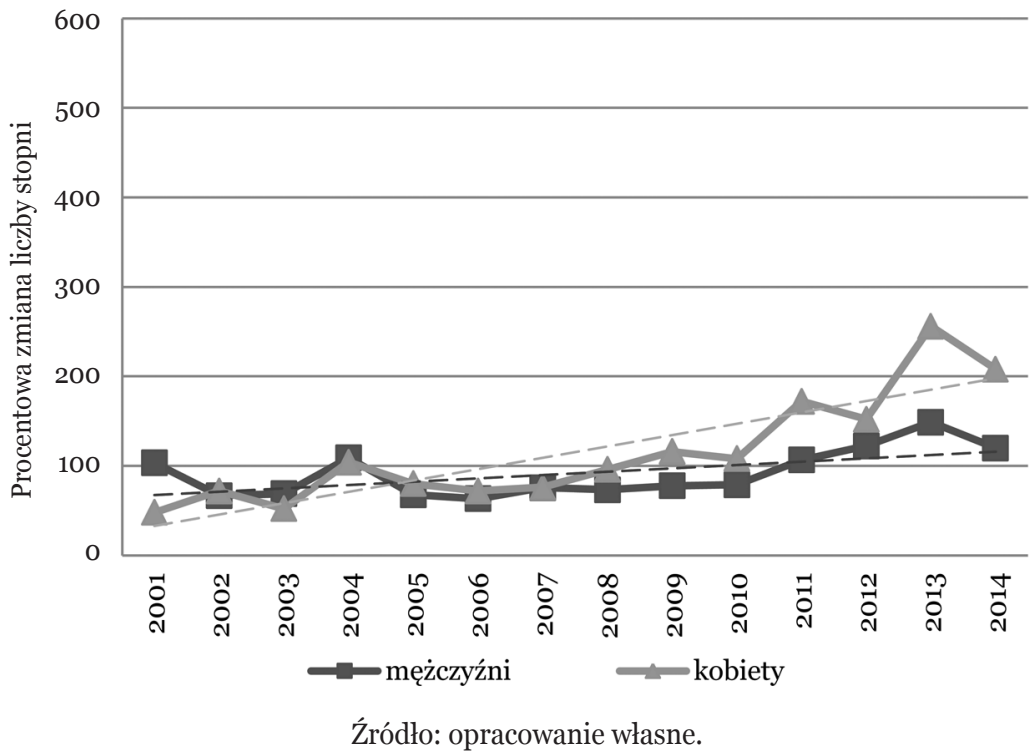


Wykres 24. Procentowa zmiana liczby nadanych stopni doktora habilitowanego obszar nauk przyrodniczych

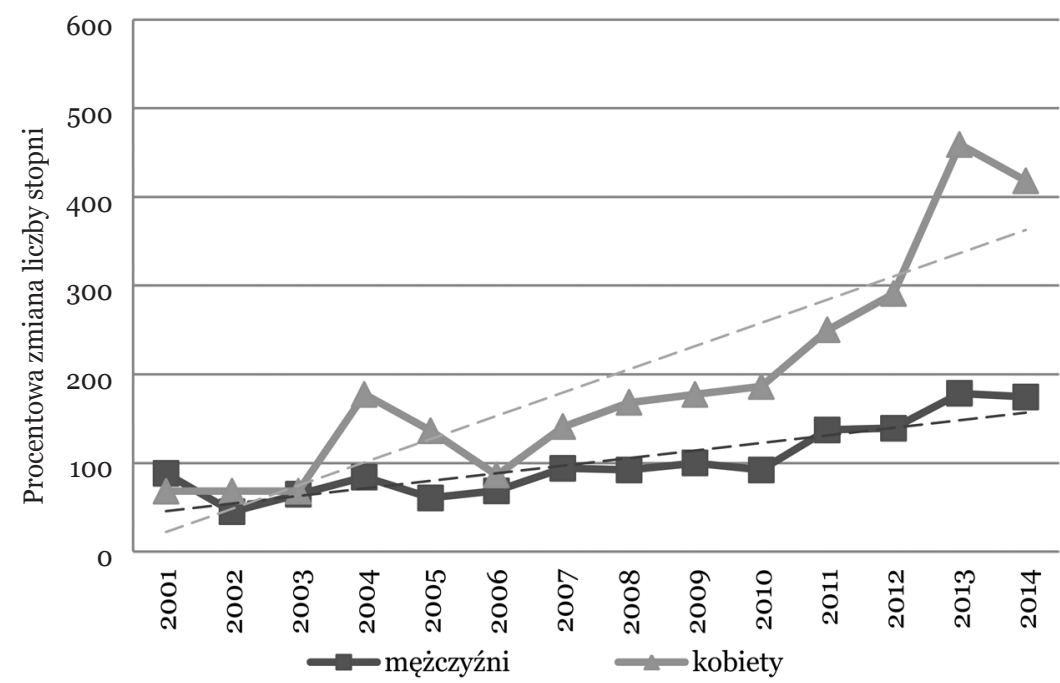

Źródło: opracowanie własne.

Wykres 25. Procentowa zmiana liczby nadanych stopni doktora habilitowanego obszar nauk technicznych

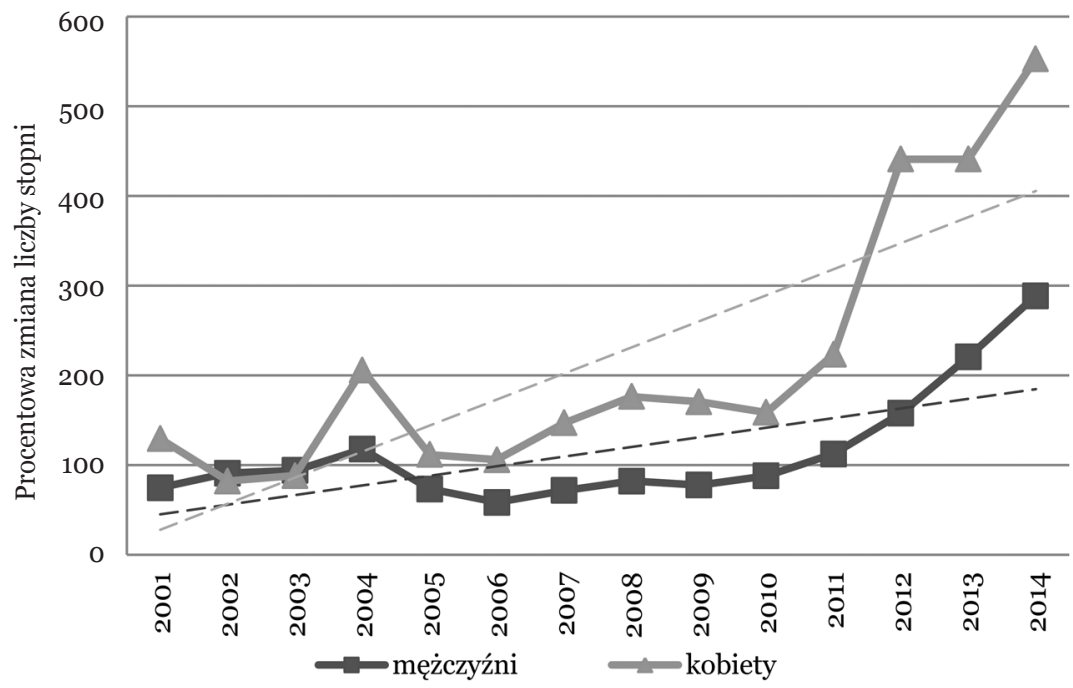

Źródło: opracowanie własne. 
Wykres 26. Procentowa zmiana liczby nadanych stopni doktora habilitowanego obszar nauk rolniczych, leśnych i weterynaryjnych

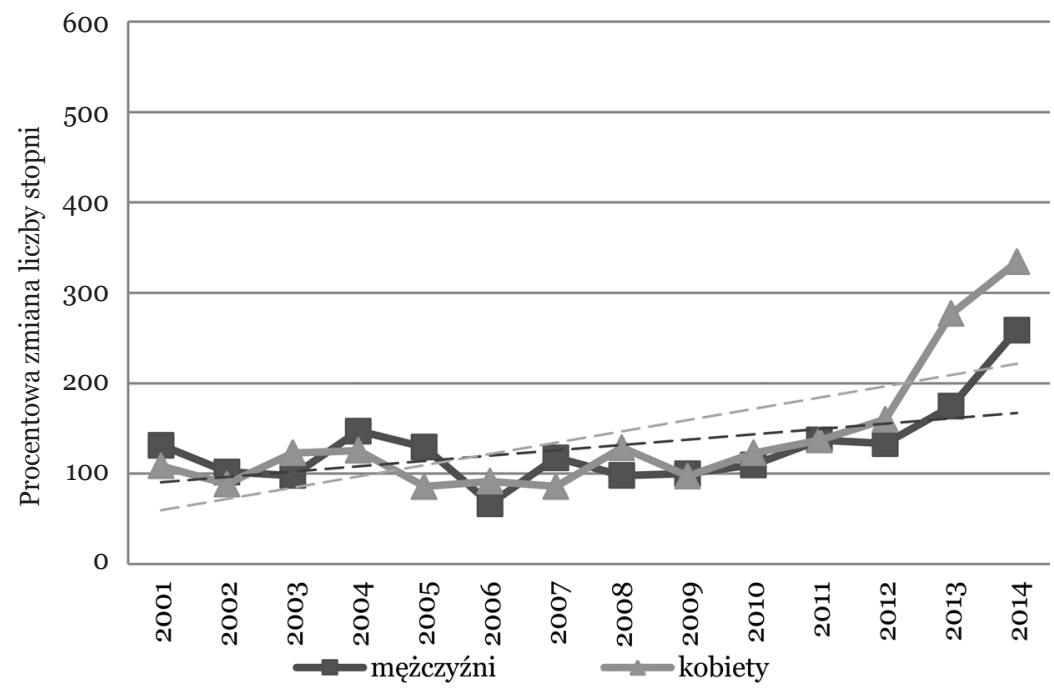

Źródło: opracowanie własne.

Wykres 27. Procentowa zmiana liczby nadanych stopni doktora habilitowanego obszar nauk medycznych i nauk o zdrowiu oraz nauk o kulturze fizycznej

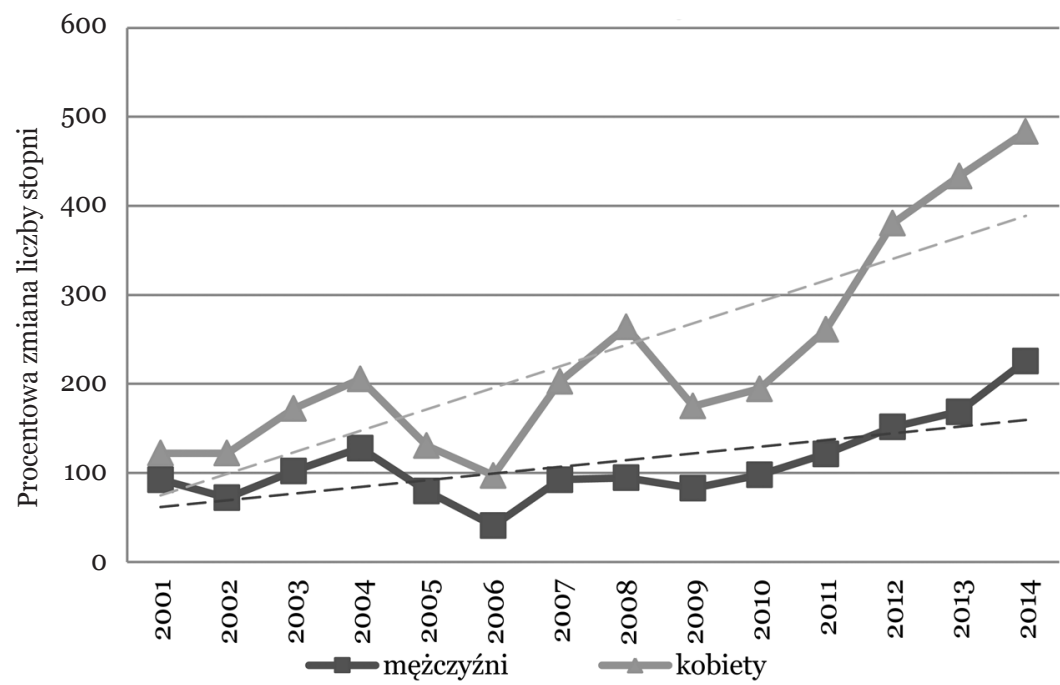

Źródło: opracowanie własne. 
Wykres 28. Procentowa zmiana liczby nadanych stopni doktora habilitowanego obszar sztuki

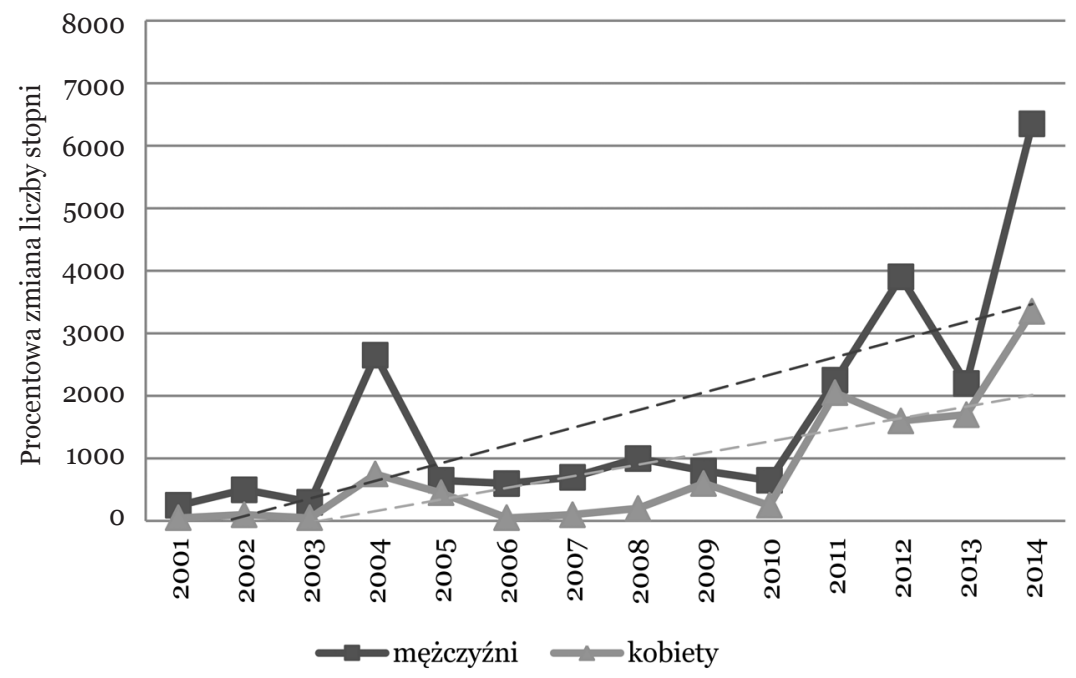

Źródło: opracowanie własne.

Zbadajmy teraz, jaki jest przeciętny wiek kobiet i mężczyzn uzyskujących stopień doktora habilitowanego i jak zmienia się on w czasie. Wykresy 29 i 30 przedstawiają udziały procentowe kobiet i mężczyzn, którzy uzyskali stopień doktora habilitowanego w różnym wieku.

W tym przypadku widzimy, zarówno dla kobiet, jak i dla mężczyzn, wyraźną tendencję do odmładzania osób, które zdobywają habilitację. I tak, udział procentowy kobiet w wieku 35-44 lat przerósł udział kobiet o dekadę starszych w 2013 r. W przypadku mężczyzn miało to miejsce jeszcze wcześniej, bo w 2009 r. Oprócz zdecydowanej tendencji wzrostowej dla tej grupy wiekowej występującej zarówno wśród mężczyzn, jak i kobiet, u obu płci obserwuje się tendencje spadkowe dla stopni uzyskiwanych przez osoby starsze: w przedziale 45-54 i 55-64 lata, chociaż udział tych ostatnich w latach 2003-2010 przejściowo wzrósł.

Ogólnie tendencja jest bardzo pozytywna: stopień doktora habilitowanego najczęściej uzyskują obecnie (od 2008 r.) osoby w wieku 35-44 lata, czyli o dekadę młodsze niż w latach 2000-2007.

Wcześniejsze uzyskanie stopnia doktora habilitowanego powinno skutkować wcześniejszym uzyskaniem tytułu profesora. W kolejnej części artykułu zobaczymy, czy tak się dzieje. 
Wykres 29. Udział procentowy w zależności od wieku w liczbie nadanych stopni doktora habilitowanego - kobiety

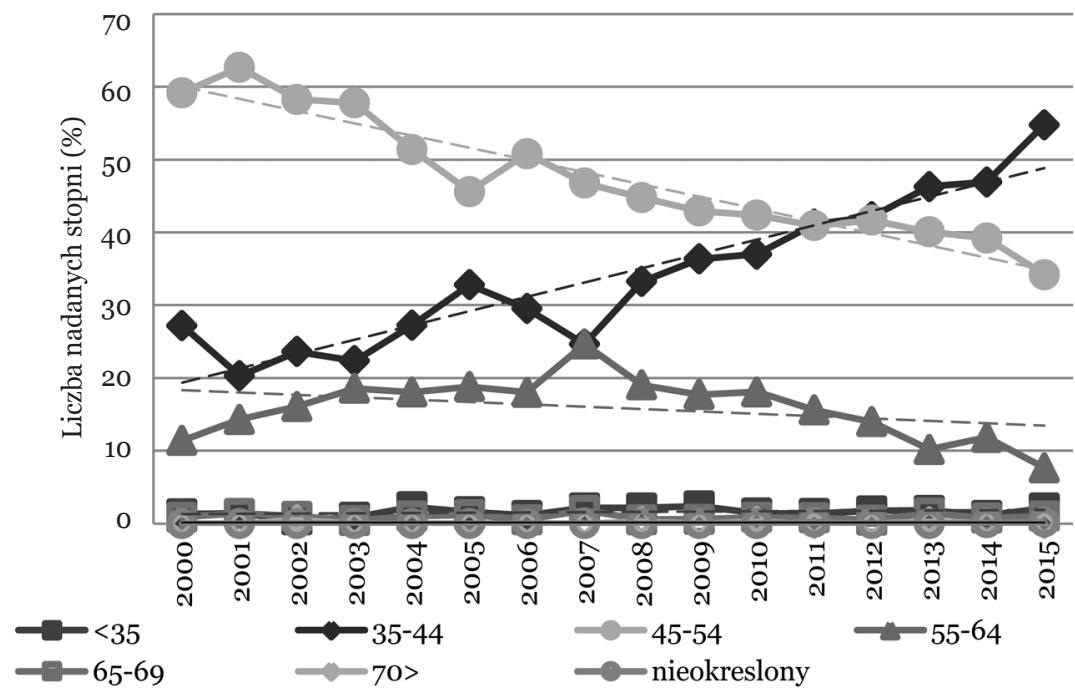

Źródło: opracowanie własne.

Wykres 30. Udział procentowy w zależności od wieku w liczbie nadanych stopni doktora habilitowanego - mężczýnini

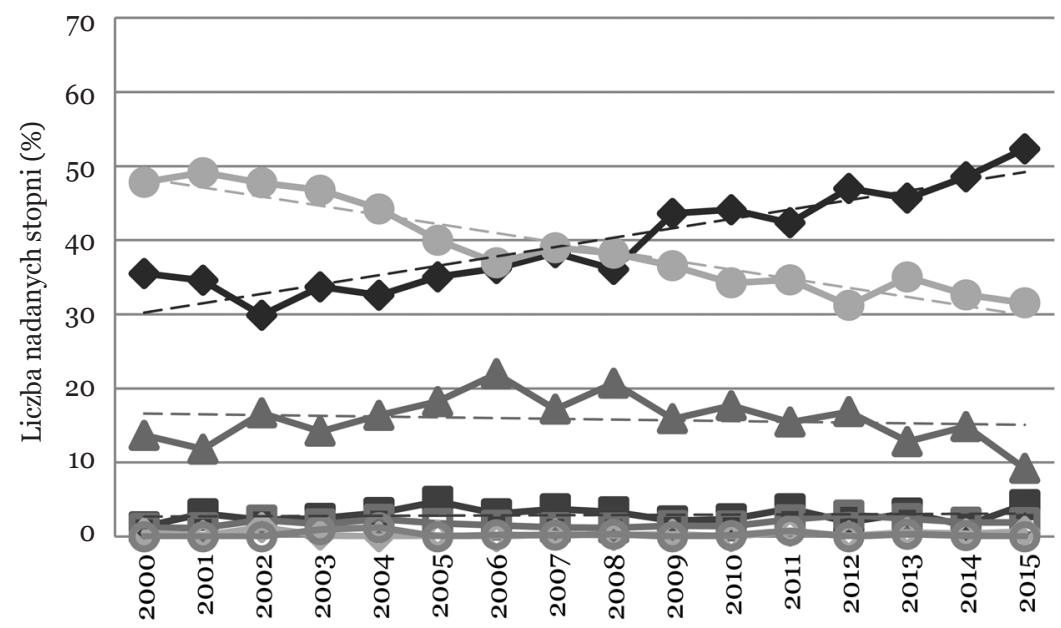

$-<35-35-44-2-45-54-55^{-64}-65-69-70>-$ nieokreslony

Źródło: opracowanie własne. 


\subsection{Tytuł naukowy profesura i profesora sztuki}

Jak wiadomo, tytuł profesora nie jest przyznawany przez gremia naukowe, ale przez Prezydenta RP na podstawie rekomendacji Centralnej Komisji do spraw Stopni i Tytułów. Można więc uznać, że przyznawanie tytułu profesora jest elementem polityki naukowej państwa, a liczba tytułów przyznanych w poszczególnych dziedzinach wskazuje na najbardziej (i najmniej) rozwijane przez państwo dziedziny. Ponadto żaden przepis prawa nie określa konieczności uzyskiwania tytułu profesora, czyli nie ma w tym przypadku żadnej daty granicznej (jak w przypadku stopnia doktora habilitowanego) wskazującej na konieczność uzyskania tego tytułu.

Analizując dane przedstawione na wykresie 31, można zauważyć dwa silne trendy: malejący dla lat 2001-2008, kiedy to liczba nadawanych tytułów z roku na rok zdecydowanie malała (z około 800 w 2002 r. do zaledwie 400 w 2006 r.), i trend rosnący dla lat 2008-2015 (w 2008 r. nadano niecałe 400 tytułów, podczas gdy w 2014 r. prawie 1000, czyli 2,5 raza więcej). Czy trend wzrostowy się utrzyma? $\mathrm{Na}$ to pytanie będzie można odpowiedzieć dopiero za kilka lat. Przy gwałtownie rosnącej liczbie habilitacji powinien on się utrzymać, gdyż naturalnym efektem habilitacji powinno być uzyskanie tytułu profesora.

Wykres 31. Liczba nadanych tytułów profesora w kolejnych latach

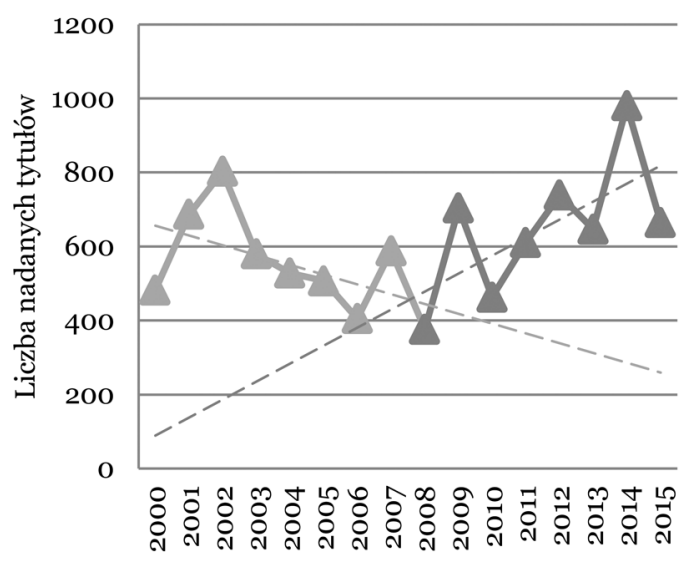

Źródło: opracowanie własne.

Sprawdźmy teraz, czy liczba tytułów przyznawanych dla poszczególnych obszarów jest jednakowa i czy jest ona stała w kolejnych latach. Wyniki stanowiące odpowiedź na to pytanie zawiera wykres 32 . Widać na nim odbicie ogólnych zależności, o których pisałem wyżej - rok 2008 można traktować jako granicę trendów. Jed- 
Wykres 32. Zależność liczby nadanych w danym roku tytułów profesora od obszaru nauk, w którym stopień został nadany

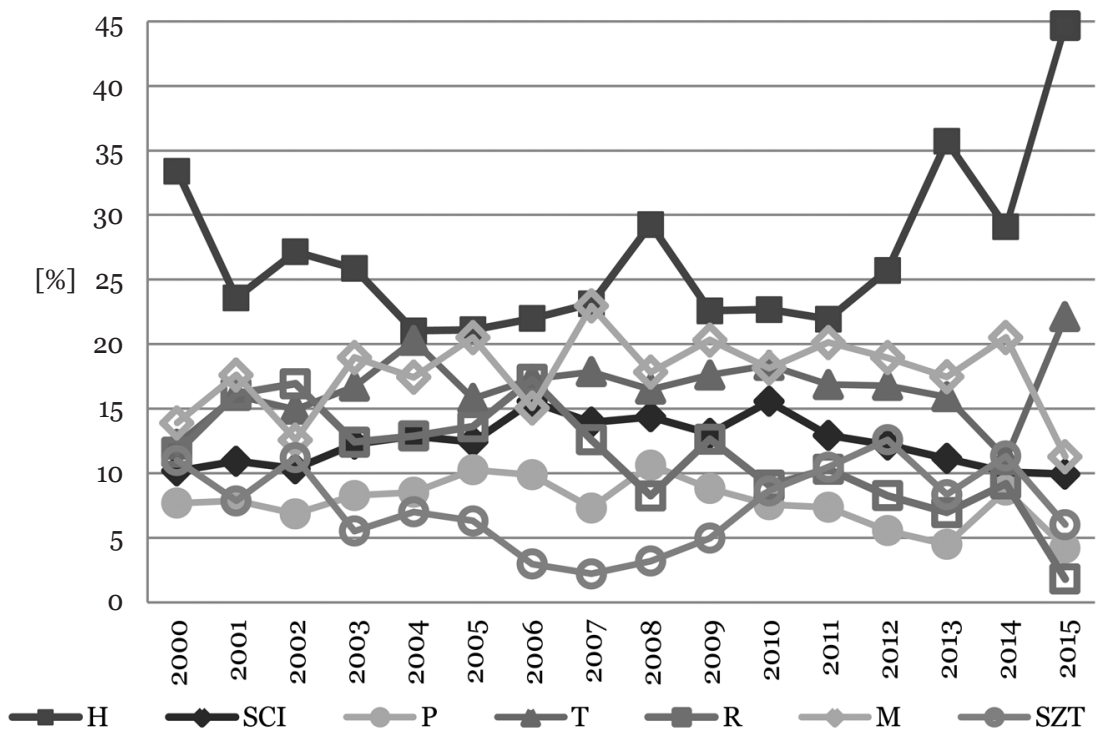

Źródło: opracowanie własne.

nak obraz, jaki wyłania się z analizy zależności liczby nadanych tytułów od obszaru nauki lub sztuki, jest nieco bardziej złożony.

W obszarach nauk medycznych i nauk o zdrowiu oraz nauk o kulturze fizycznej, a także w obszarze nauk ścisłych w latach 2000-2008 obserwujemy wzrost, a od 2009 r. spadek procentowego udziału osób z tych obszarów w liczbie nadawanych tytułów naukowych. Odwrotny efekt można zaś dostrzec w obszarze nauk humanistycznych i społecznych: mniej więcej do 2011 r. obserwujemy spadek, a po tym roku widać bardzo szybki wzrost udziału procentowego tytułów nadawanych w tym obszarze. W obszarze sztuki udział tytułów zmienia się cyklicznie: po początkowym spadku (2000-2007) nastąpił chwilowy wzrost (2007-2012), a po nim znowu spa$\operatorname{dek}$ (2012-2015).

W obszarach nauk przyrodniczych oraz rolniczych, leśnych i weterynaryjnych widać wyraźny spadek procentowego udziału tytułów w całym badanym okresie, natomiast w obszarze nauk technicznych od 2003 r. udział procentowy nadanych tytułów jest mniej więcej stały.

Uogólniając: w ostatnich latach częściej niż w poprzednich latach nadawane są tytuły w obszarze nauk humanistycznych i społecznych podczas gdy liczba tytułów w obszarze nauk medycznych i nauk o zdrowiu oraz nauk o kulturze fizycznej, obszarze nauk 
ścisłych i obszaru nauk przyrodniczych oraz obszarze nauk rolniczych, leśnych i weterynaryjnych jest stała lub maleje.

Zobaczmy teraz, czy płeć ma jakieś znaczenie dla nadawanych tytułów profesora - zależność liczby nadanych tytułów w poszczególnych latach od płci osób je uzyskujących przedstawia wykres 33. Wynika z niego, że tytuły naukowe nadal nadawane są znacznie częściej mężczyznom i ich przewaga w tym zakresie jest coraz większa.

Wykres 33. Zależność liczby nadanych w danym roku tytułów profesora od płci

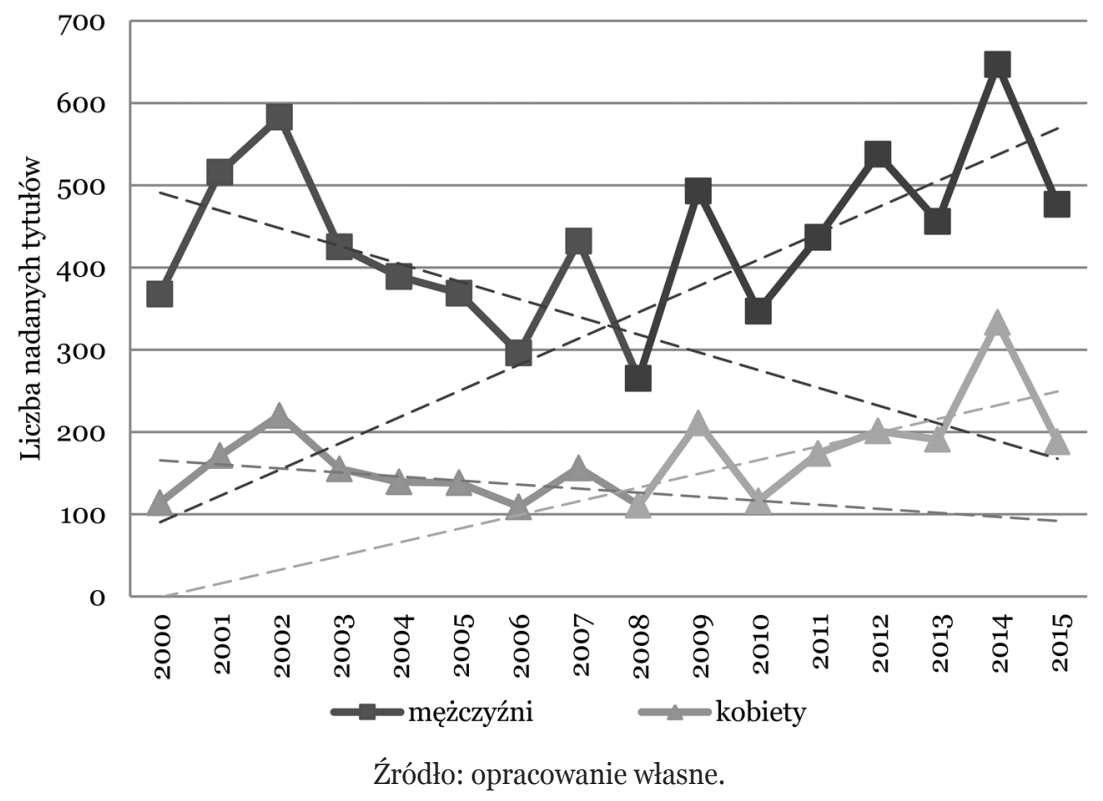

Tak wygląda porównanie liczb bezwzględnych. Przeanalizujmy teraz zmianę procentową liczby nadanych tytułów dla osób danej płci. Szczegóły przedstawiono na wykresie 34, gdzie ukazano procentową zmianę liczby nadanych tytułów $\mathrm{w}$ kolejnych latach w zależności od płci w odniesieniu do liczby stopni nadanych w $2000 \mathrm{r}$. Analizując trendy przedstawione na tym wykresie, można stwierdzić, że o ile w okresie spadku liczby nadawanych tytułów (2000-2008) zmiana procentowa liczby tytułów nadanych kobietom i mężczyznom jest równa, to w okresie wzrostu (od 2008 r.) obserwuje się wyraźnie szybszy wzrost procentowy liczby tytułów nadawanych kobietom. Wynika to jednak z początkowej bardzo dużej dysproporcji (w 2000 r.) w liczbie tytułów nadawanych kobietom i mężczyznom. Z kolei wykres 35 przedstawia wyniki otrzymane poprzez odniesienie liczby nadanych osobom danej płci tytułów naukowych w danym roku do najniższej liczby nadanych tytułów 
Wykres 34. Procentowa zmiana liczby nadanych tytułów profesora w kolejnych latach w zależności od płci w odniesieniu do liczby stopni nadanych w $2000 \mathrm{r}$.

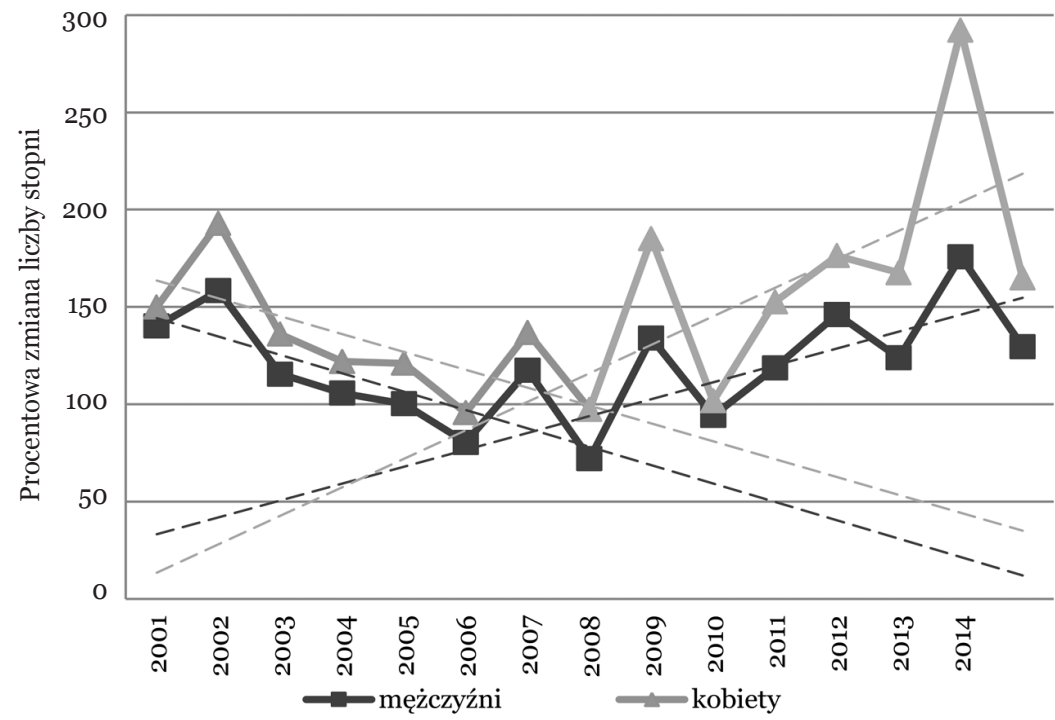

Źródło: opracowanie własne.

Wykres 35. Procentowa zmiana liczby nadanych tytułów profesora w kolejnych latach w zależności od płci w odniesieniu do liczby stopni nadanych w 2008 r.

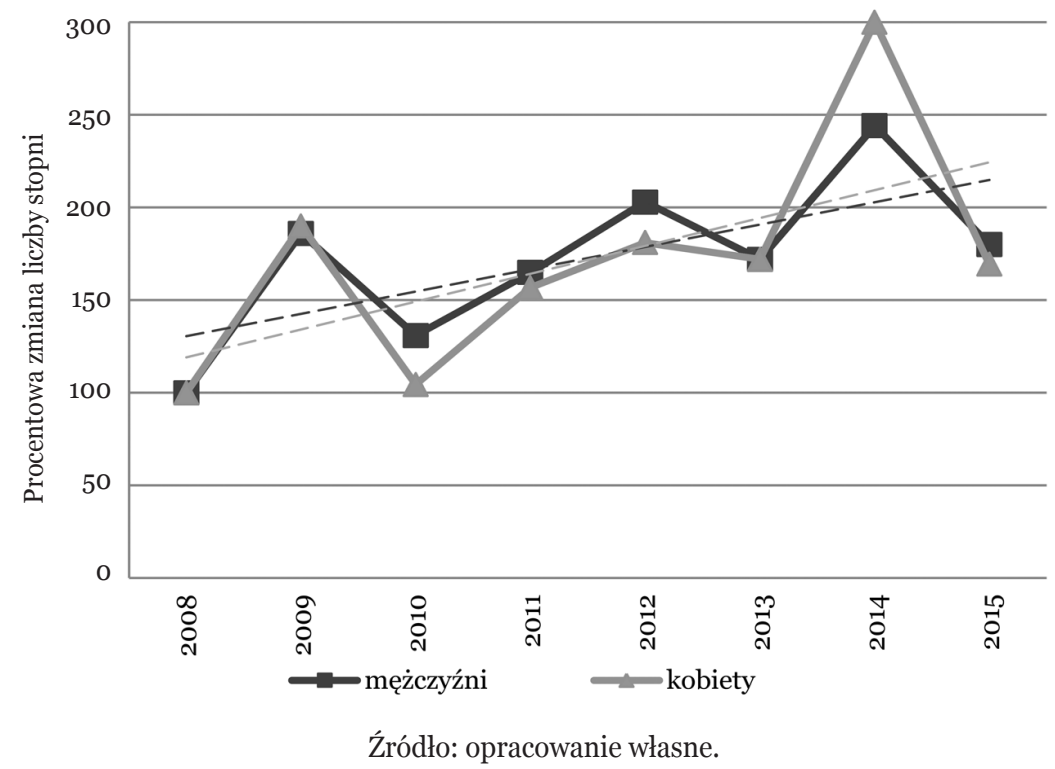


w badanym okresie, czyli liczby tytułów nadanych w 2008 r. (ze względu na większą obiektywność takiego podejścia dalej, analizując zmiany procentowe, będziemy odnosić liczbę nadanych tytułów do liczby tytułów nadanych w 2008 r.). Tutaj wyraźnie widać, że w ostatnich 8 latach trend wzrostowy dla procentowej zmiany liczby nadawanych tytułów był prawie jednakowy zarówno wśród mężczyzn, jak i kobiet.

Sprawdźmy, czy zaobserwowana tendencja ma odbicie w rozkładach procentowych liczby tytułów nadawanych w poszczególnych obszarach - wyniki takiej analizy przedstawiono na wykresach 36-42. Jak łatwo zauważyć, tendencje dla obydwu płci we wszystkich przypadkach mają ten sam charakter - jeżeli zmiana liczby dla mężczyzn ma tendencję rosnącą, to dla kobiet również, podobnie dla tendencji malejącej.

W trzech pierwszych obszarach (wykresy 36-38) tendencje w liczbie tytułów nadanych osobom obu płci są identyczne: w obszarze nauk przyrodniczych nie widać ani tendencji wzrostowej, ani spadkowej, w obszarze nauk ścisłych istnieje niewielka tendencja wzrostowa (wzrost o około $20 \%$ w ciągu 8 lat), a w obszarze nauk humanistycznych i społecznych widać bardzo wyraźną i stałą tendencję wzrostową (wzrost o ponad $150 \%$ w ciągu 8 lat).

W pozostałych obszarach obserwujemy wyraźną rozbieżność pomiędzy tendencją procentowej zmiany liczby stopni dla każdej z płci, przy czym: w obszarze nauk technicznych i obszarze nauk medycznych i nauk o zdrowiu oraz nauk o kulturze

Wykres 36. Procentowa zmiana liczby nadanych tytułów profesora obszar nauk humanistycznych i społecznych

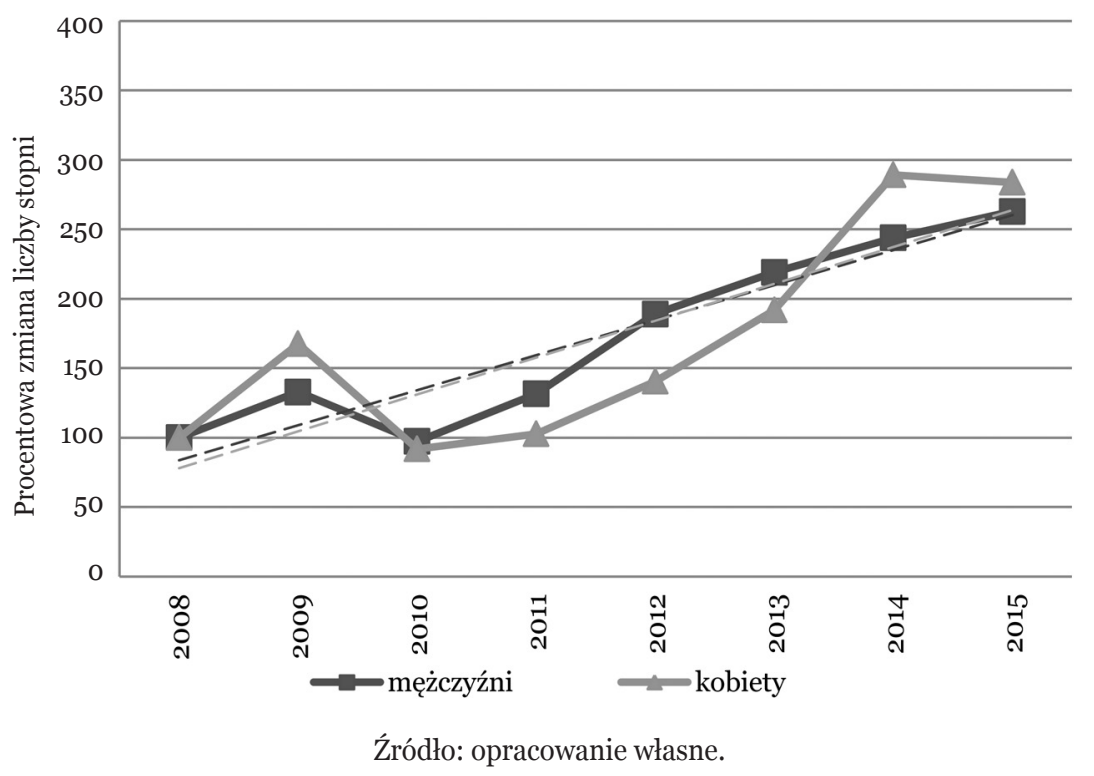


Wykres 37. Procentowa zmiana liczby nadanych tytułów profesora obszar nauk ścisłych

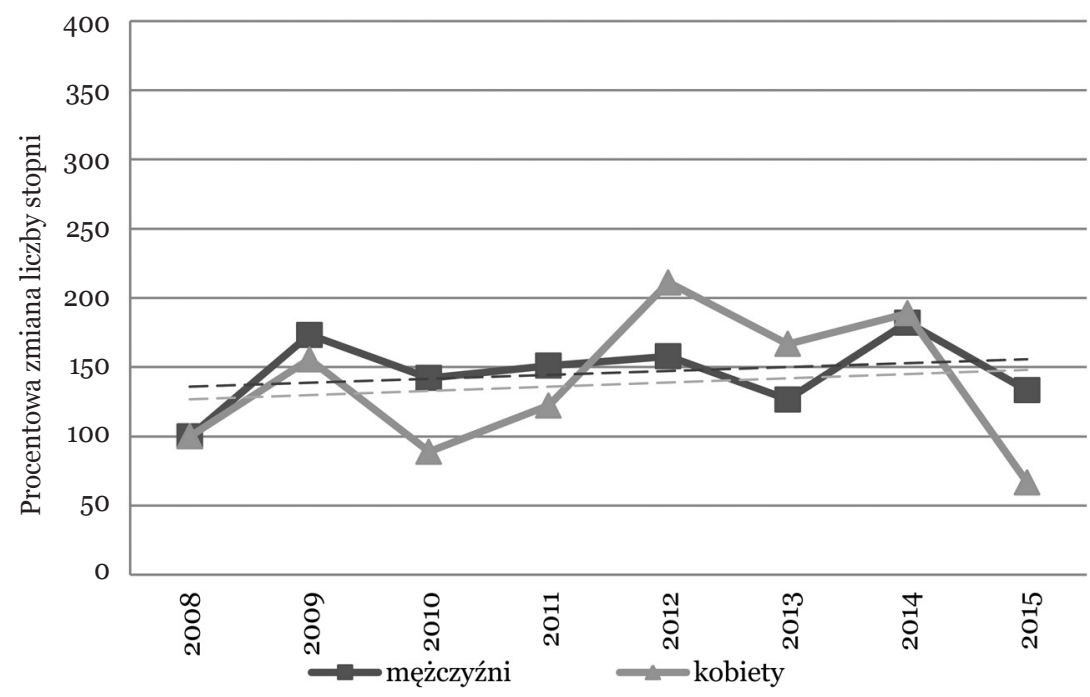

Źródło: opracowanie własne.

Wykres 38. Procentowa zmiana liczby nadanych tytułów profesora obszar nauk przyrodniczych

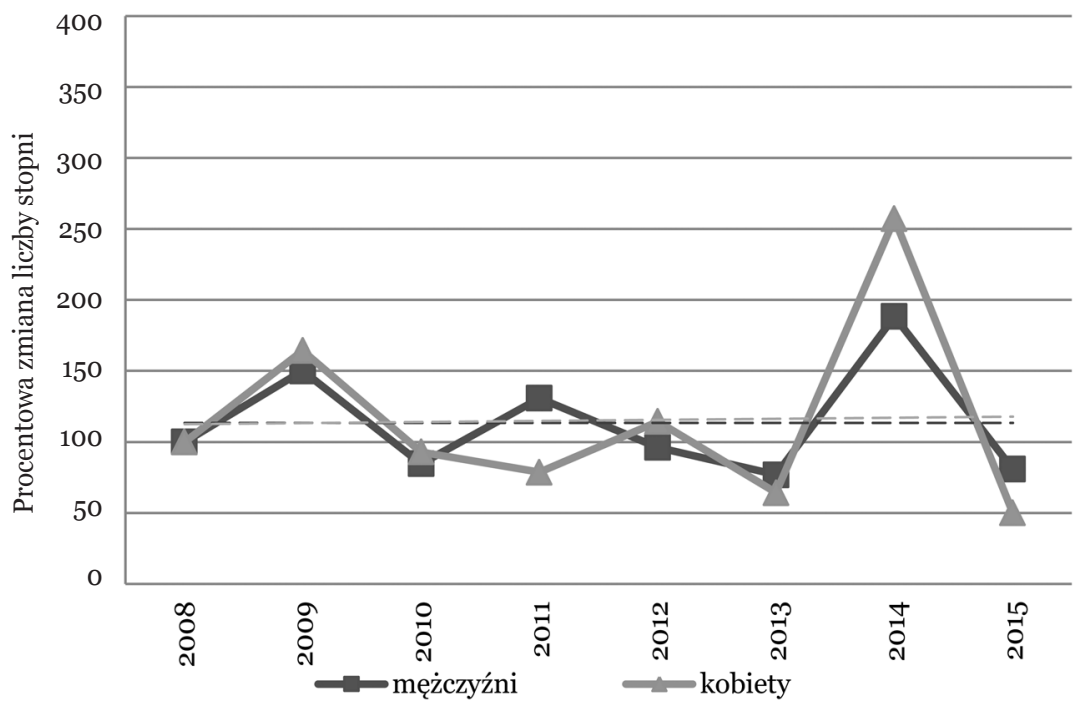

Źródło: opracowanie własne. 
Wykres 39. Procentowa zmiana liczby nadanych tytułów profesora obszar nauk technicznych

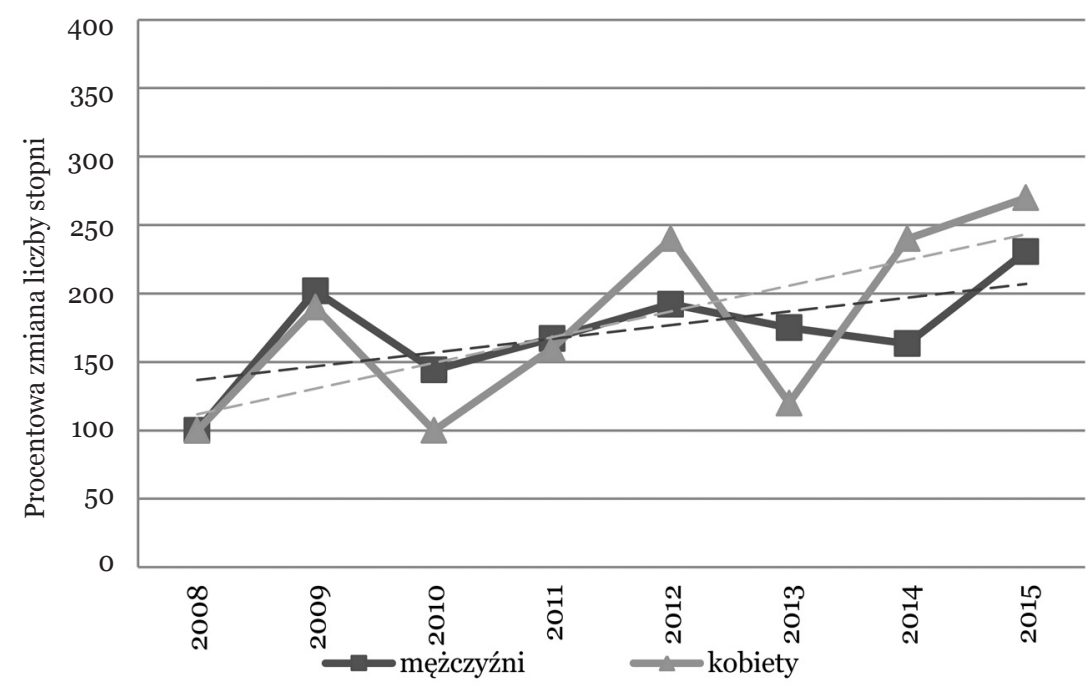

Źródło: opracowanie własne.

Wykres 40. Procentowa zmiana liczby nadanych tytułów profesora obszar nauk rolniczych, leśnych i weterynaryjnych

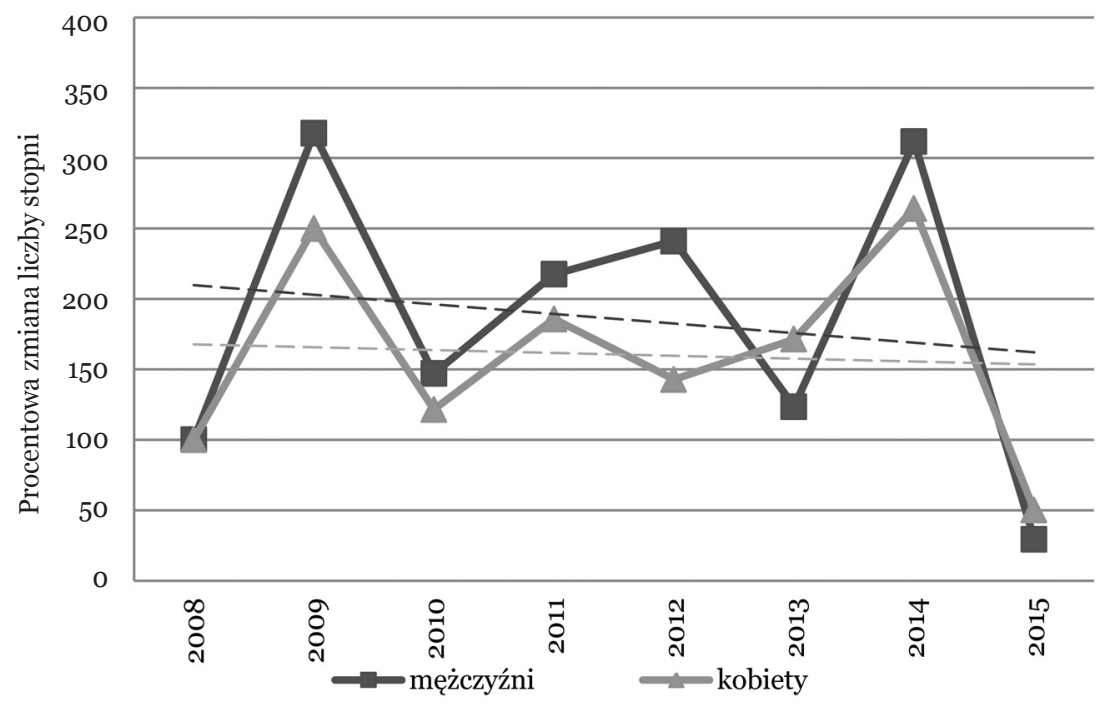

Źródło: opracowanie własne. 
Wykres 41. Procentowa zmiana liczby nadanych tytułów profesora obszar nauk medycznych i nauk o zdrowiu oraz nauk o kulturze fizycznej

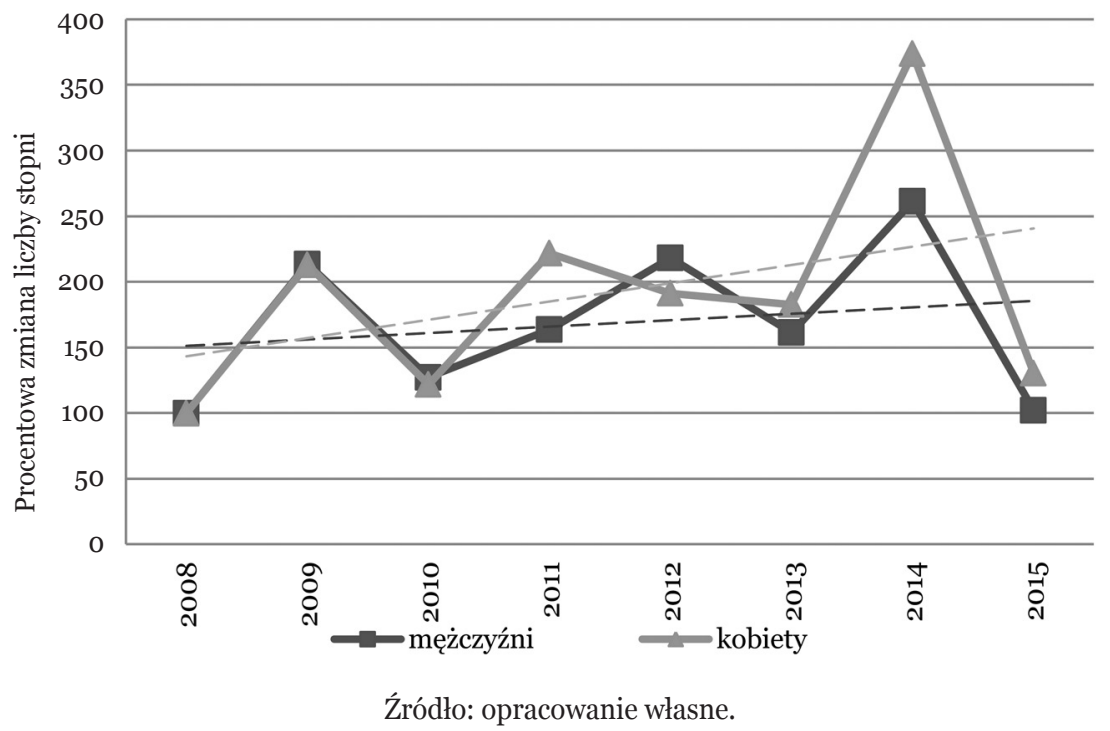

Wykres 42. Procentowa zmiana liczby nadanych tytułów profesora obszar sztuki

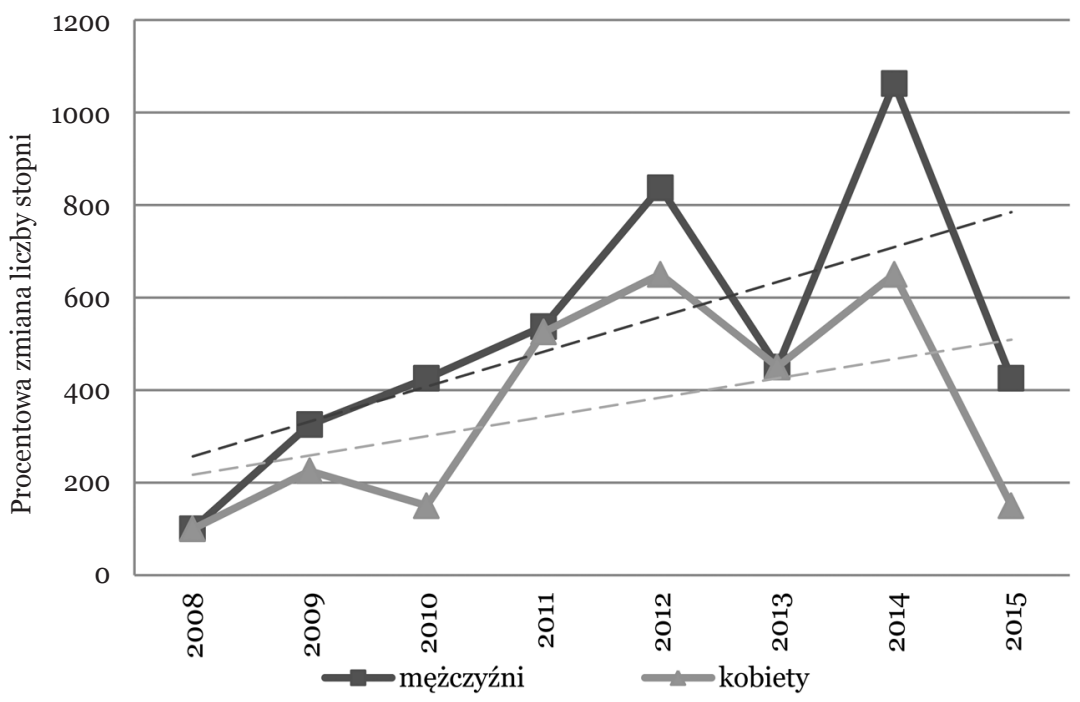

Źródło: opracowanie własne. 
fizycznej występuje tendencja wzrostowa i wzrost dla liczby tytułów nadanych kobietom jest wyraźnie szybszy; w obszarze nauk rolniczych, leśnych i weterynaryjnych obserwuje się tendencję spadkową, przy czym spadek liczby nadawanych tytułów jest wśród kobiet wolniejszy i wreszcie w obszarze sztuki widzimy silną tendencję wzrostową, przy czym wzrost liczby tytułów profesora sztuki jest znacznie większy dla tytułów nadawanych mężczyznom.

Można z tego wysnuć następujący wniosek: dla przeważającej liczby obszarów zmiana procentowa liczby tytułów nadawanych kobietom ma tendencje do szybszego wzrostu lub wolniejszego spadku niż w przypadku mężczyzn. Tylko dynamiczny wzrost liczby tytułów profesora sztuki nadawanych mężczyznom powoduje wyrównanie globalnych tendencji dla obu płci.

Sprawdźmy teraz, czy zadziwiająca tendencja, którą zauważono wcześniej (Rodzik 2009), do nadawania tytułu profesora osobom coraz starszym nadal istnieje, zwłaszcza w świetle wyraźnego obniżenia, o dekadę, wieku, w którym najczęściej uzyskiwany jest stopień naukowy doktora habilitowanego. Zależności udziału procentowego liczby mężczyzn i kobiet w określonym przedziale wieku w poszczególnych latach wśród osób, którym nadano tytuł profesora, przedstawiono na wykresach 43 i 44 .

Wykres 43. Udział procentowy w zależności od wieku w liczbie nadanych tytułów profesora - kobiety

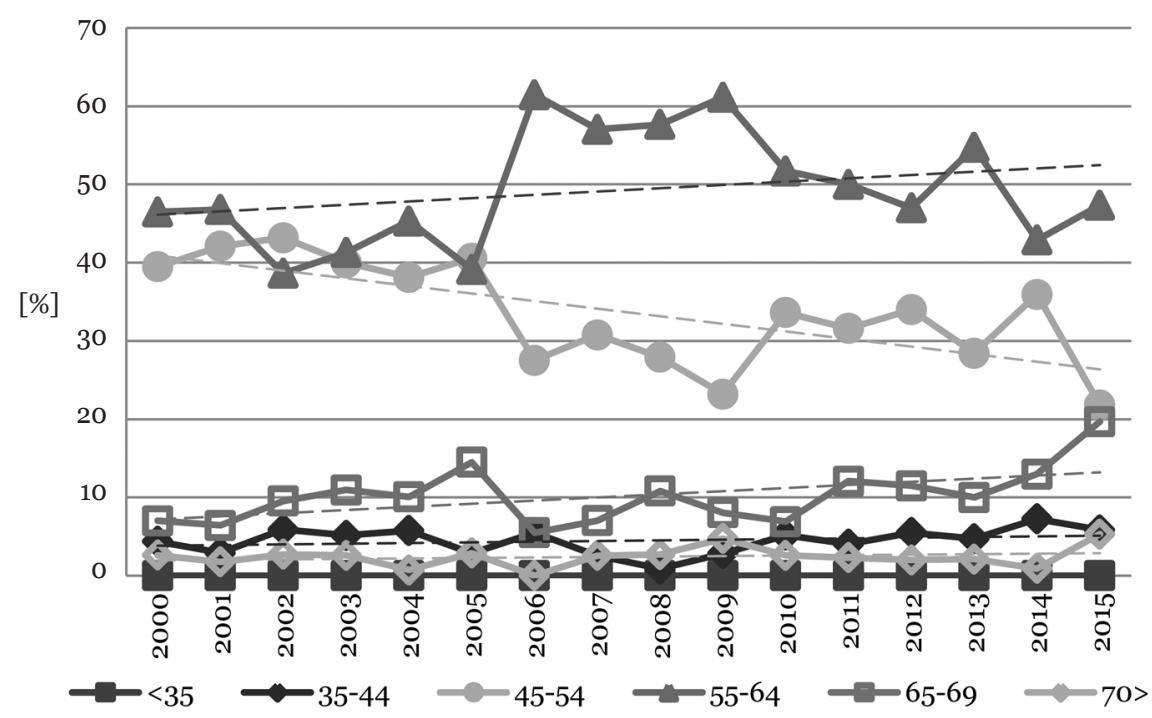

Źródło: opracowanie własne. 
Wykres 44. Udział procentowy w zależności od wieku w liczbie nadanych tytułów profesora - mężczyźni

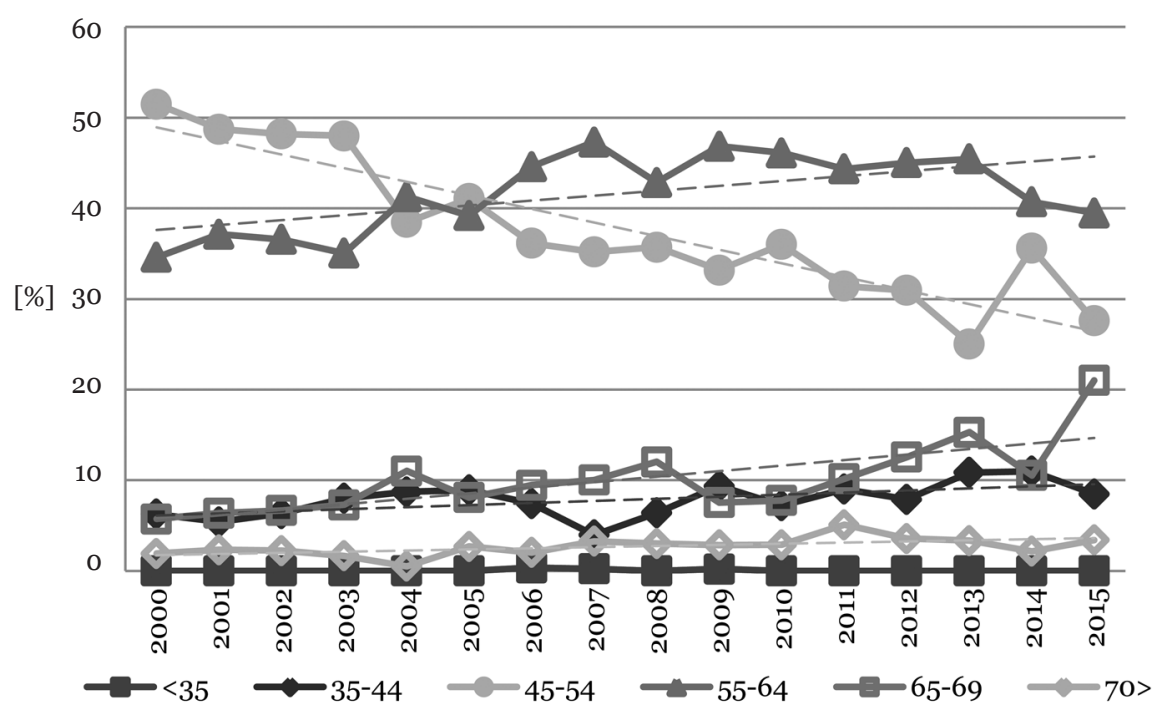

Źródło: opracowanie własne.

Jak widać, w żadnym z tych dwóch przypadków nie ma „cudownych dzieci” w latach 2000-2015 nadano tylko trzy tytuły profesora osobom, które nie osiągnęły jeszcze 35. roku życia. Dotyczy to zresztą tylko mężczyzn - żadna kobieta nie uzyskała tytułu w tak młodym wieku.

Niestety, trend nadawania tytułów osobom coraz starszym nadal się utrzymuje. Nie jest wprawdzie już tak wyraźny i silny jak do 2009 r., ale nadal zdecydowanie więcej osób (zarówno kobiet, jak i mężczyzn) w wieku 55-64 lat otrzymuje tytuł profesora niż osób o dekadę młodszych. Przypomnijmy, że do 2003 r. wśród mężczyzn obserwowaliśmy przypadek odwrotny - to mężczyźni w wieku 45-54 lat uzyskiwali najwięcej stopni. W przypadku kobiet sytuacja nie była tak oczywista, ale liczba tytułów uzyskiwanych przez nie w wieku 45-54 i 55-64 lat była mniej więcej równa. Dodatkowo niepokoi dużo szybszy wzrost liczby osób w wieku 65-69 lat, którym nadano tytuł naukowy, w stosunku do analogicznej liczby osób w wieku 35-44 lat. Wśród kobiet w 2015 r. obserwujemy niemal zrównanie liczby tytułów nadanych osobom w wieku 65-69 lat i osobom w wieku 45-54 lat (czyli o 20 lat młodszym).

Wnioski, jakie można z tego wysnuć, nie są niestety pocieszające: tytuł profesora nadawany jest osobom coraz starszym, zarówno wśród kobiet jak i mężczyzn, co powoduje, że gwałtownie rośnie czas pomiędzy zdobyciem habilitacji, a chwilą uzyskania tytułu profesora-w porównaniu do początku XXI wieku najczęściej wynosi on około 20 lat więcej. 


\section{Podsumowanie}

Wyniki analiz zamieszczone w tym artykule można w następujący sposób podsumować:

- liczba kobiet zdobywających stopnie naukowe stale rośnie,

- wzrost liczby uczestników studiów doktoranckich nie przekłada się na liczbę nadawanych stopni doktora,

- zmiany prawne wprowadzone w $2010 \mathrm{r}$. spowodowały gwałtowny wzrost liczby nadawanych stopni doktora habilitowanego,

- wiek osób najczęściej uzyskujących stopień doktora habilitowanego obniżył się o około 10 lat,

- liczba kobiet, którym nadawany jest tytuł naukowy, rośnie, ale niewspółmiernie wolniej niż liczba kobiet uzyskujących stopnie naukowe,

- wiek osób, którym najczęściej nadawany jest tytuł naukowy, nadal rośnie,

- znacznie zwiększył się średni czas pomiędzy zdobyciem stopnia doktora habilitowanego a uzyskaniem tytułu profesora - obecnie wynosi on około 20 lat.

Ogólnie rzecz biorąc, zdecydowanie rośnie udział kobiet w badaniach naukowych, ale nauką prowadzoną na "najwyższym poziomie” (osoby z tytułem profesora) zajmują się ludzie coraz starsi.

\section{Literatura}

Jegorow, D. (2014). Zmiany w rozwoju zawodowym pracowników naukowych w kontekście zmian ilościowych w szkolnictwie wyższym. Człowiek - Gospodarka - Wspótpraca Rozwój. Perspektywa lokalna i globalna, cz. 2, CIVIS \& Sun Solution.

Kwiek, M. (2015). Uniwersytet $w$ dobie przemian. Warszawa: Wyd. Naukowe PWN.

She Figures (2016). Luxembourg: Publications Office of the European Union.

Rodzik, P. (2009). Kto zdobywa stopnie i tytuly naukowe - trochę statystyki. Sprawy Nauki. 4: strony.

Rozporządzenie Ministra Nauki i Szkolnictwa wyższego z dnia 8 sierpnia 2011 r. w sprawie obszarów wiedzy, dziedzin i sztuki oraz dyscyplin naukowych i artystycznych. Dz.U. nr 179, poz. 1065.

Uchwała Centralnej Komisji do spraw Stopni i Tytułów z dnia 23 czerwca 2003 r. w sprawie określenia dziedzin nauki i dziedzin sztuki oraz dyscyplin naukowych i artystycznych. MP nr 40, poz. 586 z późn. zm.

Ustawa z dnia 14 marca 2003 r. o stopniach naukowych i tytule naukowym oraz o stopniach i tytule w zakresie sztuki. Dz.U. nr 65, poz. 595 z późn. zm.

Ustawa z dnia 27 lipca 2005 r. Prawo o szkolnictwie wyższym. Dz.U. nr 164, poz. 1365 z późn. zm.

Ustawa z dnia 30 kwietnia 2010 r. o Polskiej Akademii Nauk. Dz.U. nr 96, poz. 619. 


\section{Academic degrees and titles: Has anything changed?}

ABSTRACT. The article is devoted to trends observed in the numbers of scientific degrees and scientific titles granted in Poland for women and men. It is shown how the numbers of scientific degrees and titles granted in consecutive years were changed due to age of person for which degree/title was granted and region of science and art for which it was granted. Analysis is made basing on data collected in the Knowledge Base for Polish Science and the cover-smokers last 16 years (2000-2015).

KEYWORDS: scientific degrees, academic titles, gender, area of scientific research

CYTOWANIE: Rodzik, P. (2016). Nadane stopnie i tytuły naukowe - czy coś się zmieniło? Nauka i Szkolnictwo Wyższe. 2(48): 139-174. DOI: 10.14746/nisw.2016.2.7. 